Article

\title{
Growing and Eating Food during the COVID-19 Pandemic: Farmers' Perspectives on Local Food System Resilience to Shocks in Southern Africa and Indonesia
}

\author{
Nicole Paganini ${ }^{1,2, *}\left(\mathbb{D}\right.$, Kustiwa Adinata ${ }^{3}$, Nomonde Buthelezi ${ }^{4}$, David Harris ${ }^{5}$, \\ Stefanie Lemke ${ }^{6,2}$ (1) , Alberto Luis ${ }^{7}$, Jennifer Koppelin ${ }^{1}$, Abdulrazak Karriem ${ }^{8}$, \\ Fezile Ncube ${ }^{9}$, Enzo Nervi Aguirre ${ }^{10}$, Tandu Ramba ${ }^{5}$, Inês Raimundo ${ }^{11}$, \\ Nedim Sulejmanović ${ }^{1}$, Haidee Swanby ${ }^{12}$, Daniel Tevera ${ }^{13}$ and Silke Stöber ${ }^{1}[$ \\ 1 Centre for Rural Development (SLE), Humboldt-Universität zu Berlin, 10115 Berlin, Germany; \\ jenniferkoppelin@web.de (J.K.); nedim@posteo.de (N.S.); silke.stoeber@agrar.hu-berlin.de (S.S.) \\ 2 Societal Transition and Agriculture, University of Hohenheim, 70599 Stuttgart, Germany; \\ ac0447@coventry.ac.uk \\ 3 Indonesian Farmers Community Network (JAMTANI), Jawa Barat 4037, Indonesia; \\ kustiwa.adinata@gmail.com \\ 4 Cape Town Research Farmer Club, Cape Town, South Africa; nomondeb3@gmail.com \\ 5 Pusbinlat Motivator-GT, Sangalla', Tana Toraja, South Sulawesi, Indonesia; \\ david.pusbinlat@gmail.com (D.H.); mtvkondoran@gmail.com (T.R.) \\ 6 Centre for Agroecology, Water and Resilience, Coventry University, Coventry CV1 5FB, UK \\ 7 Associação pela Agricultura Biológica, Biodiversidade e Desenvolvimento Sustentável, \\ Maputo, Mozambique; albertoluis1026@gmail.com \\ 8 Institute for Social Development, University of the Western Cape, Cape Town 7535, South Africa; \\ razack.karriem@gmail.com \\ 9 Hope Tariro Trust, Masvingo, Zimbabwe; fezilecz@gmail.com \\ 10 Development Practice, University of California-Berkeley, Berkeley, CA 94720, USA; \\ enzo_nervi@berkeley.edu \\ 11 Center for Policy Analysis and Department of Geography, Universidade Eduardo Mondlane, \\ Maputo 3453, Mozambique; inesmacamo@gmail.com \\ 12 Critical Food Studies, University of the Western Cape, Cape Town 7535, South Africa; haidee@polka.co.za \\ 13 Department of Geography, Environmental Studies and Tourism, University of the Western Cape, \\ Cape Town 7535, South Africa; dtevera@uwc.ac.za \\ * Correspondence: paganini@hu-berlin.de
}

Received: 15 September 2020; Accepted: 14 October 2020; Published: 16 October 2020

check for updates

\begin{abstract}
The COVID-19 outbreak forced governments to make decisions that had adverse effects on local food systems and supply chains. As a result, many small-scale food producers faced difficulties growing, harvesting, and selling their goods. This participatory research examines local small-scale farmers' challenges as farmers but also as consumers and their coping strategies during the month of April and one week in June 2020. The study was initiated and conceptualized in collaboration with small-scale farmer members of an existing research network in selected urban and rural areas in South Africa, Mozambique, Zimbabwe, and Indonesia. Participants co-designed the research, collected and uploaded data through digital survey tools, and contributed to data analysis and interpretation. A common observation across regions is that the measures imposed in response to COVID-19 highlighted and partly exacerbated existing socio-economic inequalities among food system actors. Strict lockdowns in Cape Town, South Africa, and Masvingo, Zimbabwe, significantly restricted the production capacity of small-scale farmers in the informal economy and created more food insecurity for them. In Maputo, Mozambique, and Toraja and Java, Indonesia, local food systems continued to operate and were even strengthened by higher social capital and adaptive capacities.
\end{abstract}


Keywords: COVID-19; pandemic; lockdown; small-scale farmers; local food systems; resilience; Indonesia; Mozambique; South Africa; Zimbabwe

\section{Introduction}

Worldwide, most food is produced by small-scale farmers (we use the term "small-scale farmer" and "farmer" interchangeably throughout the document), yet these farmers face hunger and vulnerability to food insecurity [1]. This becomes particularly apparent in times of shocks, such as the current COVID-19 pandemic. At the beginning of 2020, the world, and especially marginalized groups, felt the severe impact of national lockdowns in response to the novel coronavirus. Civil society actors, scholars, the FAO, and the World Food Programme (WFP) alike raised legitimate concerns about the pandemic's impact on low-income households' livelihoods and food security [2-4]. Measures considered necessary from an epidemiological perspective have resulted in devastating consequences primarily in the informal sector leading to the loss of jobs and income for millions and considerable food insecurity crises [5]. Government decisions on how and when to respond to the pandemic reflected low levels of preparedness and consultation with key stakeholders, including food system actors who questioned how to bolster food system resiliency during shocks like the COVID-19 crisis [6]. The pandemic exposed fault lines in existing food systems, such as underlying structural inequalities stemming from colonialism (and apartheid and post-apartheid, in South Africa), gender inequalities, concentration of market power in a few global companies, global supply chains and dependencies on food imports, food insecurity due to price fluctuations, and the harm caused by the industrialized agriculture sector, with severe ecosystem impacts [7,8]. Béné (2020) argues that the virus itself does not pose as much of a threat to the lives of billions as do its negative consequences on food system resilience, which is understood as the ability of households and communities to cope with shocks without having a long-term negative impact on wellbeing and functioning of these food systems [6]. Organizations such as the International Panel of Experts on Sustainable Food Systems (IPES) and the Transnational Institute as well as international scholars argue the pandemic opened opportunities for transforming current exclusionary food systems to meet societal needs [7,9-12]. The COVID-19 pandemic offers the unique opportunity to rethink and fundamentally reshape local food systems to become more just and socially inclusive, and in doing so, address the root causes of poverty and hunger.

This study is an initiative of urban, landless research farmers in Cape Town who did not want to see the COVID-19 pandemic as yet another external shock to their farming systems. Rather, they instituted co-research beyond borders to examine the specific challenges to and opportunities for food system resilience from small-scale farmers' perspectives in urban, peri-urban, and rural settings. Small-scale farmers in all research sites farm on small pieces of land; most of them apply labor-intensive techniques and do not rely on technologies.

We firmly believe that those who are most affected should be involved in mutual understanding of the challenges and, in the process, co-creating solutions. This study presents results that emerged from weekly surveys conducted during four weeks in April and the first week of June 2020 with 707 small-scale farmers from five regions in the Global South: Java and Toraja in Indonesia, Maputo in Mozambique, Cape Town in South Africa, and Masvingo in Zimbabwe. Small-scale farmers from these regions co-designed the study, collected data, participated in the analysis and interpretation of the results, and contributed writing to this paper. Our co-research is inspired by a people's science approach [13] and provides in-depth insights into the experiences of small-scale farmers in these areas.

\subsection{Theoretical Framework}

We drew on several frameworks to investigate the impact of COVID-19 on local food systems to inform our own theoretical framework for the study (Figure 1). We applied an adapted food system resilience framework based on Béné $(2020,16)$, understanding food system resilience as an opportunity 
to alleviate faults and build capacities (coping capacity, adaptive capacity, transformative capacity) to ameliorate future uncertainty and/or shocks [14,15]. We also drew on Martin's $(2012,5)$ work on resilience in food systems, which is defined as "the ability of the system to undergo anticipatory or reactionary reorganization of form and/or function so as to minimize impact of a destabilizing shock" [16]. Moreover, we referred to Frankenberger et al. (2012) to discuss underlying stress factors on resilience (e.g., institutional, structural, socio-economic, and environmental) that influence the level of vulnerability. Long-term issues, such as climate change or increasing marginalization, either aggravate the vulnerability of households or increase their adaptive capacity [17]. Communities' or households' coping capacities cushion shocks while their adaptive capacities build on the immediate environment within the family and community (social capital) and provide the flexibility to cope with shocks. Finally, transformative capacity is the solution space that provides the opportunity to create longer-term change to sustainably improve the community and household food system.

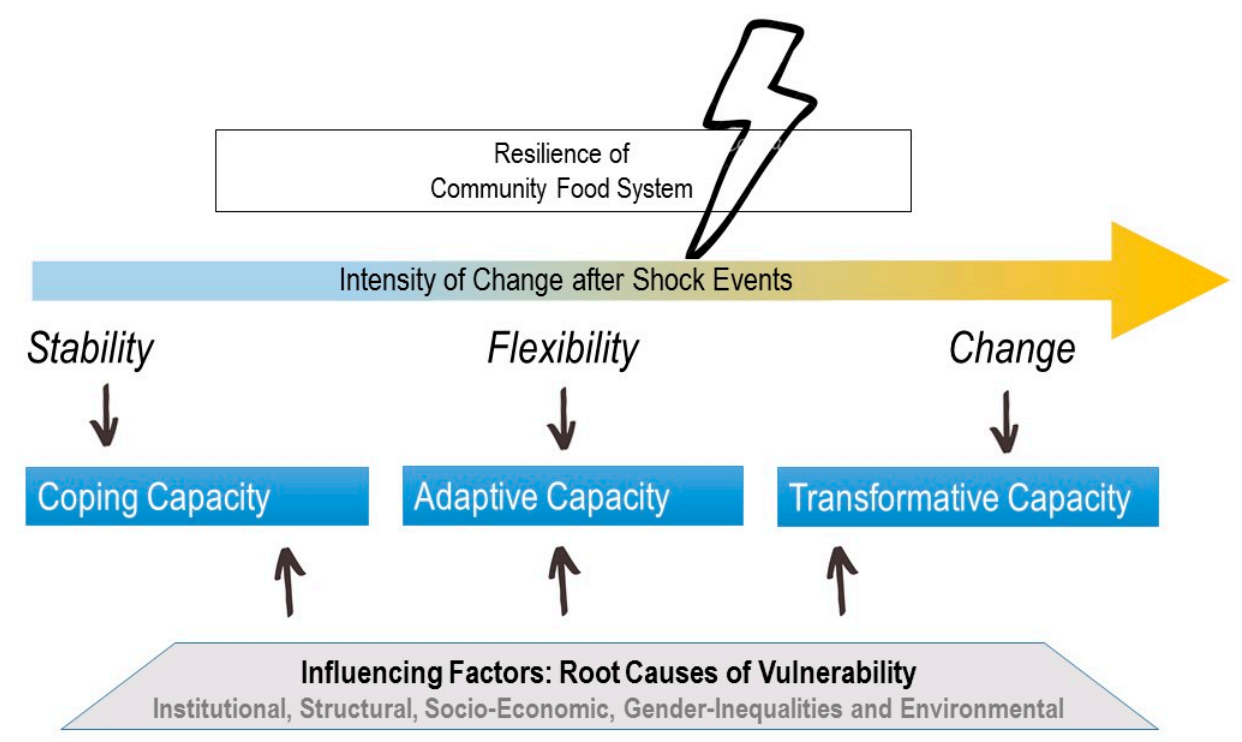

Figure 1. Resilience framework of local food systems impacted by shocks. Adapted from Béné (2020) [6] and Frankenberger et al. (2012) [17].

As Béné (2020) points out, there is little information on resilience of local food systems from different actor perspectives. This research seeks to contribute to this gap by providing a small-scale farmer perspective on the impact of COVID-19 and food system resilience [6]. We shed light on the challenges experienced by small-scale farmers and the strategies they employed while navigating COVID-19 restrictions, while also highlighting how these challenges and strategies vary by gender. Co-researchers collected farmer perspectives from five case study areas in the Global South, which all were linked in previous research projects coordinated with this consortium: rice farmers in Java, Indonesia, who sell their produce to local consumers; farmers in Toraja, Indonesia, who sell produce at local farmers markets; peri-urban farmers in Maputo, Mozambique, who sell produce within their neighborhoods; urban farmers in Cape Town, South Africa, who create distribution channels within townships; and farmers in the Masvingo area of Zimbabwe, who distribute their produce to the city center. We aim to answer the following specific questions:

1. What challenges are female and male small-scale farmers facing when producing food and selling their goods during the lockdown/state of emergency?

2. How do small-scale farmers describe the impact of the COVID-19 measures on their communities and households and on their access to food? Do male and female farmers experience these impacts differently? 
3. Have small-scale farmers perceived price changes for food commodities during the lockdown/state of emergency? If so, have these price changes affected female and male farmers' food sources and eating habits?

4. What coping strategies did small-scale farmers employ? Did women and men employ different strategies?

\subsection{Study Context}

The following sub-chapters describe the five research sites' demography with respect to agricultural systems, COVID-19 infections, and mitigation strategies employed during the study period (April to June 2020).

The study was initiated as an ad-hoc study with existing partners from different projects. While Indonesia and Mozambique introduced social restrictions, partners in South Africa and Zimbabwe were confronted with lockdowns and curfews. The COVID-19 pandemic has emphatically highlighted the fundamental need to develop shock resilience mechanisms in agrarian systems. The study describes experiences from five research sites in four countries, each differing in local conditions (such as climate, history, and land rights) as well as the COVID-19 responses observed, yet sharing commonalities as low-income countries with limited access to advanced technology and high levels of susceptibility to shocks (such as climate change or the loss of biodiversity).

\subsubsection{Indonesia}

With 262 million inhabitants spreading over an archipelago of more than 17,000 islands, Indonesia is the fourth most populated country in the world. Agriculture contributes only 14 percent to GDP, but employs 33 percent of the labor force in 25 million holdings [18,19]. In fact, 93 percent of farmers are very small-scale, as they produce on an average of 0.6 hectares.

The informal sector is very much dominated by agriculture with almost half $(45 \%)$ of the informal workers being employed in this sector [20]. While the national poverty rate is estimated at 9.2 percent, 56.5 percent of informal workers and 18.0 percent of smallholder farmers live in poverty [20].

Small-scale farmers from two areas of Indonesia participated in the study: Java and Toraja. The densely populated Java island is the heart of rice production, with almost every farm producing rice. However, the typical 0.25 hectare plot does not allow for food or income sufficiency, meaning farmers in the area rely on rice imports and off-farm informal income. The rural food region of Toraja on Sulawesi island is mountainous and a popular tourist destination. 80 percent of the population relies on agriculture for income with small-scale farmers growing mainly rice and coffee on less than 2 hectares, along with some vegetables and cocoa.

As the pandemic particularly puts the livelihoods of poor and informally employed people at risk, Indonesian farmers could be disproportionally affected. After initially downplaying the crisis and underreporting cases and deaths, the Indonesian government implemented a strategy to mitigate the economic downturn, including putting "large-scale social restrictions" in place and signing them into law on 31 March 2020. This regulation allowed local governments-districts or cities-to restrict the movement of individuals and goods within a region upon approval of the Ministry of Health. Local governments were, therefore, able to choose systems that they felt best suited local needs with restrictions ranging from no limitations of movement to quasi-lockdowns and strict stay-at-home orders. Importantly, the most severe restrictions occurred during Eid al-Fitr (Idul Fitri), which prevented internal migrants from visiting their families. A timeline of new infections and government response is provided in Figure 2. 


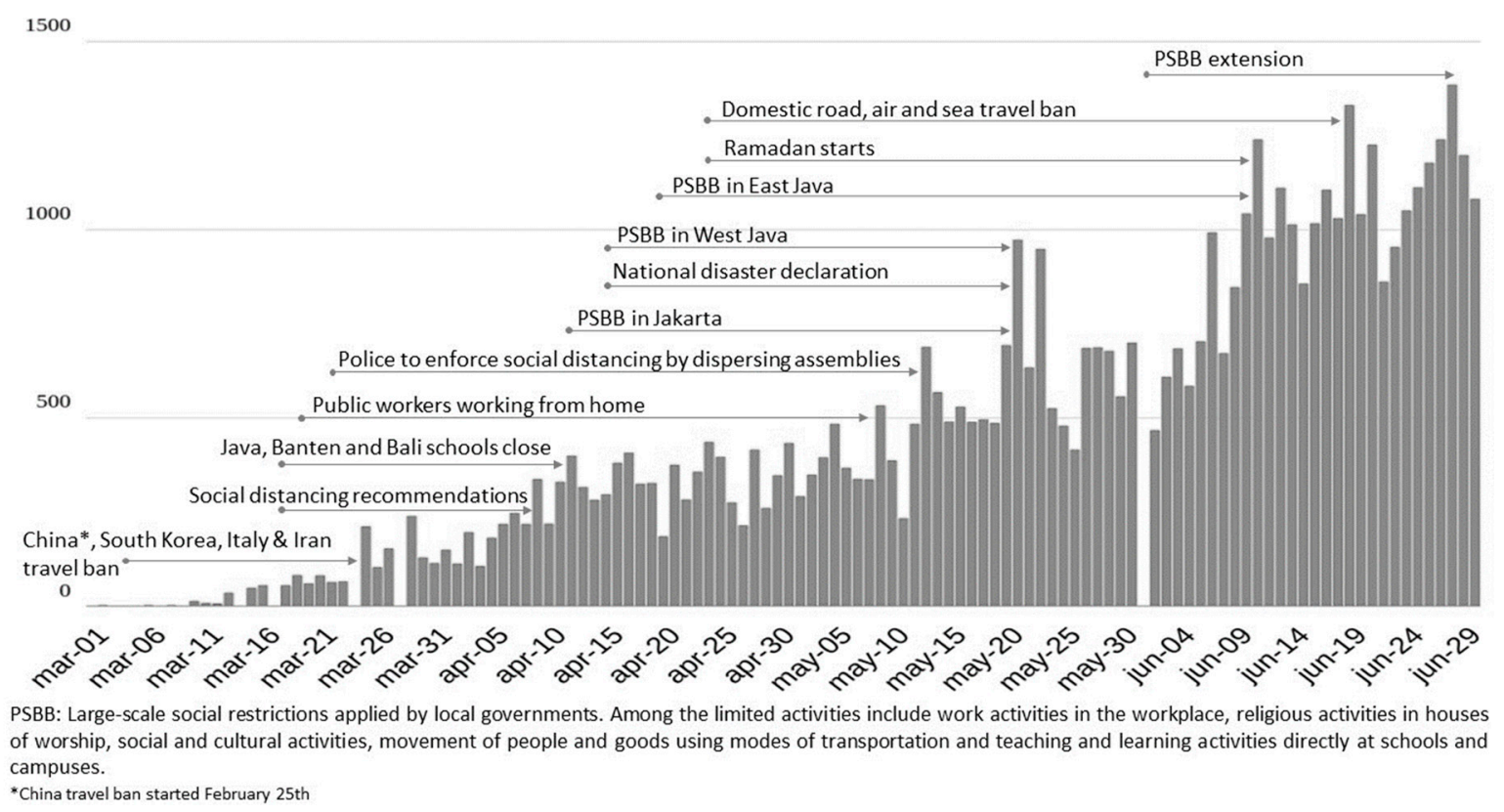

Figure 2. Daily cases and COVID-19 measures imposed by the Indonesian government (March-June 2020). Source: own illustration, adapted from WHO Coronavirus Dashboard [21].

\subsubsection{Mozambique}

While Mozambique relies on small-scale family farming in rural areas, the capital Maputo is a major transshipment port for the region and is highly dependent on food imports. Maputo faces severe food insecurity, with $70 \%$ of the cities' population food insecure [22]. The lack of food availability lies in structural poverty; markets and market structure; policy dysfunction; relative affordability of different types of food; food safety challenges wrought by inadequate urban infrastructure; and inadequate household food storage, refrigeration, and cooking technologies [23]. Unlike other African capitals, population growth in Maputo city is not rapid [23], and the majority of the population depends on the informal economy (about 70\% of the population) or urban agriculture and fisheries (15\%) [24]. In fact, Maputo has an economically important peri-urban agriculture sector, which employs and feeds some ten thousand city farmers who are organized in associations and their informal intermediaries [25]. Though peri-urban agriculture positively contributes to food availability, external factors continue to threaten food security in the area, particularly urban migration; natural shocks including floods, droughts, and cyclones (most notably, cyclones Idai and Kenneth in 2019); and armed insurgencies in the central and northern regions.

Though Mozambique's reported COVID-19 case load has remained relatively low since their first reported case in March 2020, the increasing number of cases remained a concern during the study period, particularly as neighboring South Africa reported heavy infection rates and is a crucial trade partner. The national government declared a state of emergency, restricted movement in public space, and closed international borders, though allowing limited food imports. Since then, the country has declared states of emergency thrice, each time limiting the movement of people and severely impacting the economy and food production (see Figure 3). 
60

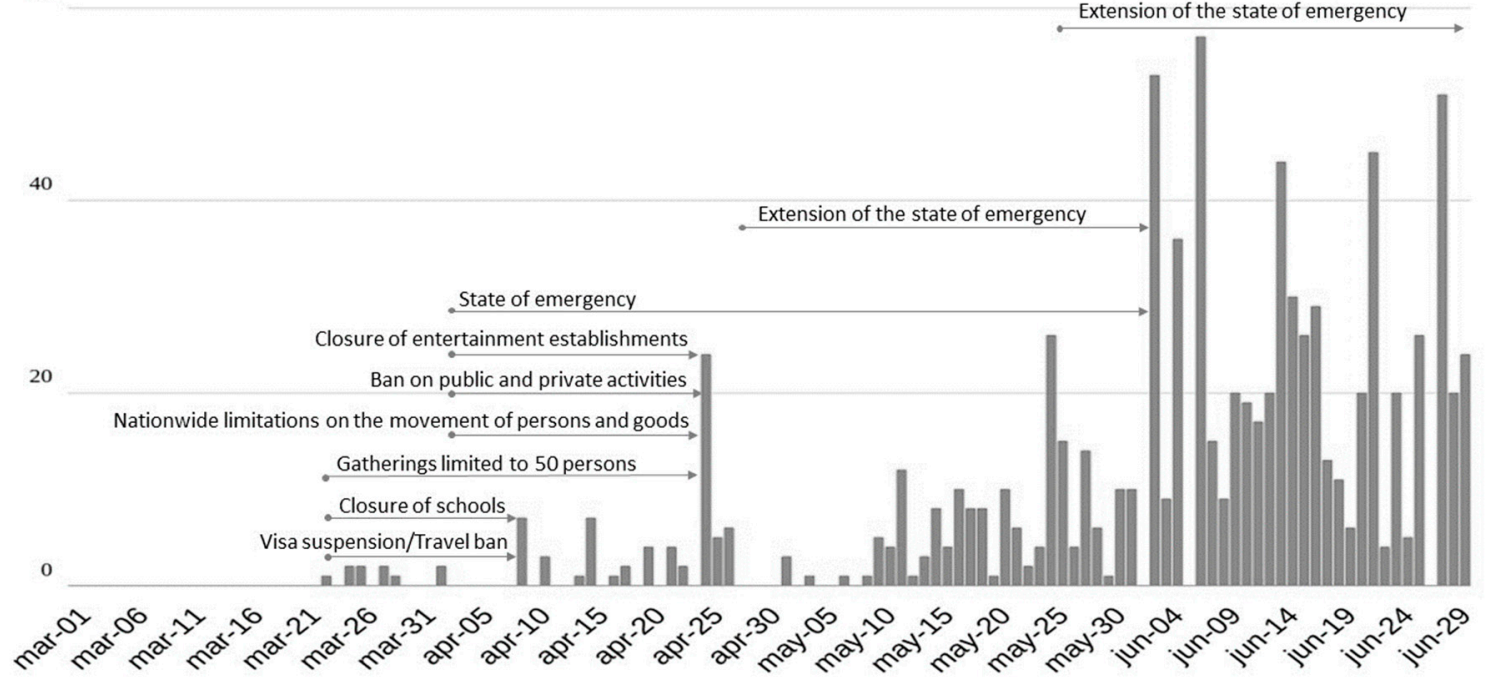

Figure 3. Daily cases and COVID-19 measures imposed by the Mozambican government (March-June 2020). Source: own illustration, adapted from WHO Coronavirus Dashboard [21].

\subsubsection{South Africa}

In addition to high unemployment and underemployment rates, South Africa faces high hunger rates. In 2014, the South African National Health and Nutrition Examination Survey (SANHANES) found that $26 \%$ of South Africans face hunger, with a further $28 \%$ being in danger of being subjected to hunger [26]. In Cape Town, thousands of urban dwellers grow food in backyards to mitigate this issue. Depending on the season, urban farmers-mostly elderly, unemployed women—cultivate between 100 and 200 larger food gardens (100 $\mathrm{m}^{2}-1 \mathrm{ha}$ ) on public grounds [25]. Most urban farmers are integrated into formal food value chains affiliated with intermediary programs that sell produce from township food gardens to restaurants, hotels, and markets in better-off city quarters [25].

Hunger and unemployment became more severe during the COVID-19 pandemic; in May 2020, the Human Sciences Research Council reported that 34 percent of South Africans went to bed hungry [26,27]. The South African government imposed one of the strictest lockdowns in the world (see Figure 4), including curfews and closing the informal sector, which significantly impacted the food system and flow of goods [28]. This resulted in massive job losses, especially in the informal sector, which employs one in every six South Africans-particularly people of color $[28,29]$. The strict lockdown also meant that 9 million learners who receive meals through the National School Nutrition Programme were denied access to meals, thus exacerbating hunger in poor neighborhoods [30]. Alarmingly high levels of food insecurity persist in low-income households-especially for people of color-with almost three quarters of low-income households experiencing hunger and the greatest burden falling on informal dwellers, female-headed households, and households with irregular sources of income [31]. For these households, the COVID-19 lockdown has been disproportionately severe. 


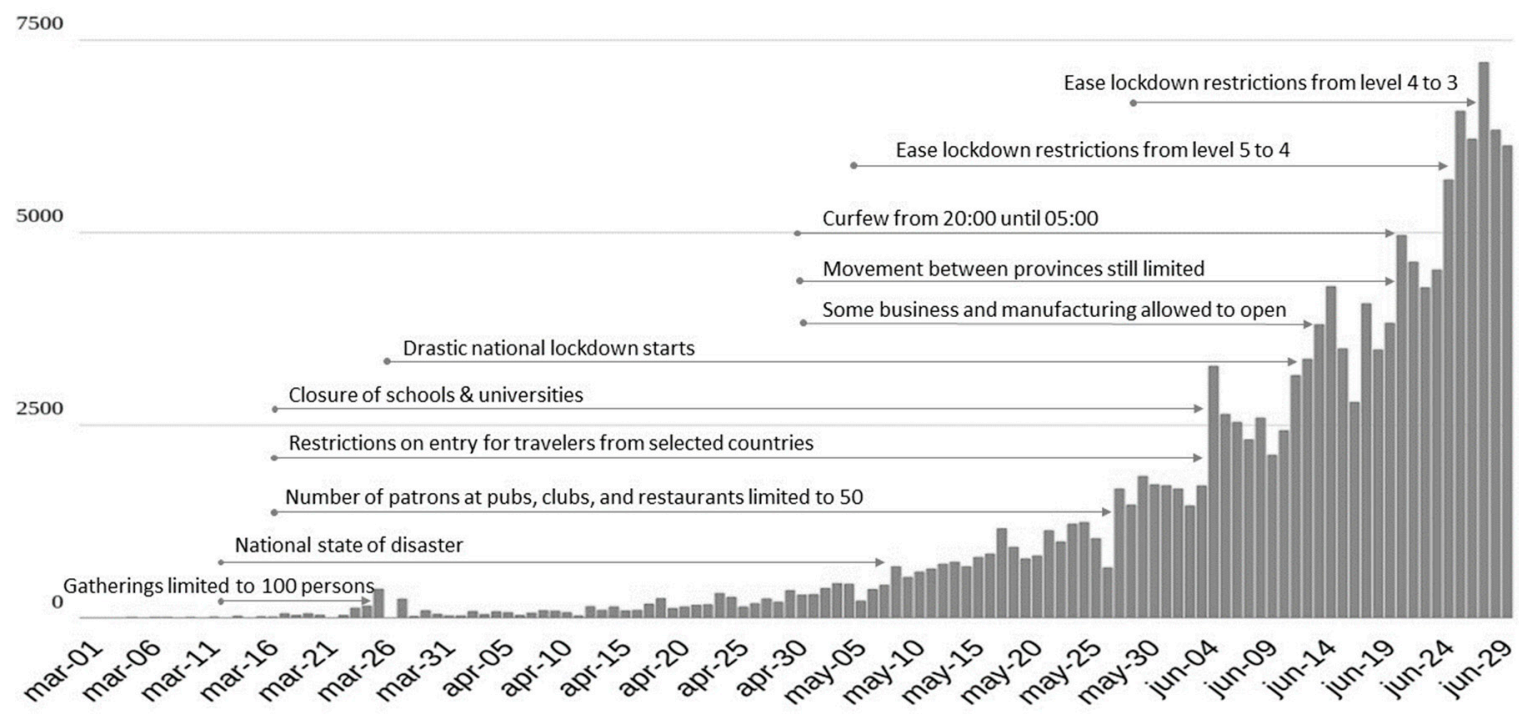

Figure 4. Daily cases and COVID-19 measures imposed by the South African government (March-June 2020). Source: own illustration, adapted from WHO Coronavirus Dashboard [22].

This study took place in Cape Town where levels of diabetes, hypertension, and obesity are all higher than the national average. These non-communicable diseases have been linked with poverty and nutrition transition leading to the consumption of cheap, high-fat, and sugary foods [26-28,32,33]. Diabetes and hypertension were the most prevalent co-morbidities present in Western Cape COVID-19 deaths by mid-June 2020 [34].

COVID-19 has revealed the deep-rooted race and class inequalities, with people of color already experiencing the brunt of unemployment and hunger. Apartheid-era spatial planning in Cape Town under the Group Areas Act confined people of color to the city's periphery, where many continue to lack access to the formal economy [35,36].

\subsubsection{Zimbabwe}

The study area in Masvingo province is situated in the drier south-eastern lowveld of the country and has an area of $56,566 \mathrm{~km}^{2}$ and a population of about 1.5 million. The province is predominantly semi-arid and experiences erratic rainfall and frequent droughts. The cultivation of drought-resistant small grains, such as sorghum and millet, has been actively promoted by government; however, the land distribution program implemented by the Zimbabwean government two decades ago has resulted in reduced food production by both commercial and small-scale farmers in most parts of the country. Recurrent droughts and the economic meltdown have increased poverty and food insecurity in rural communal areas where farmers produce staple foods such as maize, millet, and groundnuts. Although food is readily available in supermarkets and informal food markets, many low-income households cannot meet food price increases. Home gardens in Masvingo city are an essential component of the local food systems [37,38].

By mid-March, the Zimbabwean government had declared the COVID-19 outbreak a national emergency and introduced travel restrictions and banned large gatherings. By 23 March, additional measures were introduced, including closure of national borders to non-essential travel and closure of social, entertainment, and sporting facilities. On 27 March, the government announced a 21-day nationwide lockdown that was subsequently extended with a reversal of previous restrictions on selling of alcohol (see Figure 5). 
80

Lockdown extended 'indefinitely'

60

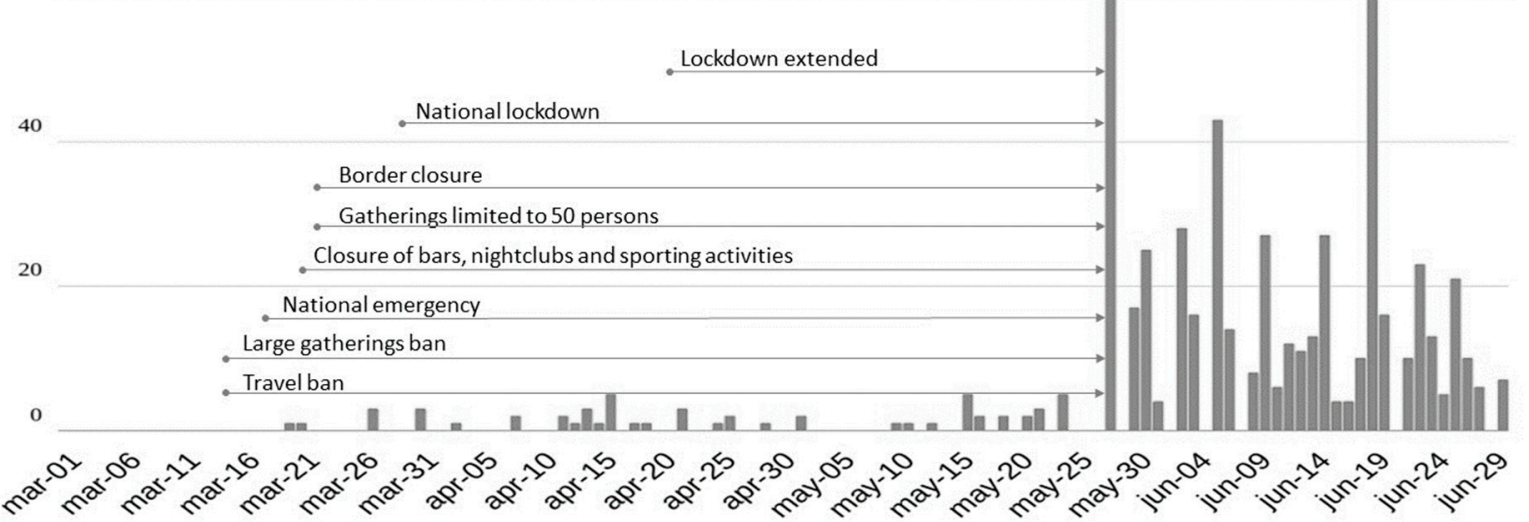

Figure 5. Daily cases and COVID-19 measures imposed by the Zimbawean government (March-June 2020). Source: own illustration, adapted from WHO Coronavirus Dashboard [21].

\section{Materials and Methods}

We carried out this study in two parts. First, we designed and conducted a digital survey using a co-research approach. We use the term "co-research" to mean research in which small-scale farmers (or co-researchers: community researchers) were involved in all steps of the research process from the design of the study to data collection, analysis, and writing. We then remotely triangulated, analyzed, and drew conclusions from the data together with local co-researching farmers. This allowed us to survey the same farmers and evaluate the changes in their perceptions over time. The data for this study were collected using the digital KoBoToolbox data collection tool in five phases: one survey per week in April 2020 and one survey in the first week of June 2020. KoBoToolbox is an open source application, which is owned and operated by Harvard Humanitarian Initiative. The tool aims to support data collection in challenging environments, humanitarian crises and aid, and international research [39].

Questionnaires were digitally available in English (Cape Town and Masvingo), Portuguese (Maputo), and Indonesian (Java and Toraja) with the validation survey containing four qualitative and 22 quantitative questions. In the process of data collection, the questionnaire was further refined and improved through constant feedback from the participants. The final questionnaire is attached as an appendix. The survey was administered to farmer members of NGOs/CBOs as follows: in Indonesia, by Jaringan Masyarakat Tani Indonesia (JAMTANI) and Motivator Kondoran; in South Africa, by the Cape Town Urban Farmer Club; in Mozambique by Associação pela Agricultura Biológica, Biodiversidade e Desenvolvimento Sustentável (Abiodes) in Maputo; and in Zimbabwe, by The Hope Tariro Trust in Masvingo. However, a limitation and potential bias in the study is that only those farmers who were able to fill in the questionnaire on their own smartphones participated. In Mozambique, enumerators conducted telephone interviews with farmers and filled in the digital survey tool. In Zimbabwe, due to poor connectivity, farmers sent their survey answers via WhatsApp and the supporting researchers entered the data into the KoBoToolbox.

Participating farmer groups joined regional WhatsApp groups, which were moderated by research facilitators for each region. The surveys were conducted in April, when lockdowns and states of emergency were first declared. In May, preliminary data analyses were shared with co-researchers and commented upon in WhatsApp groups. Co-researchers discussed and triangulated preliminary results via WhatsApp groups, made recommendations for an improved process (for example, the use of enumerators in Toraja to encourage participation where technology was prohibitive), and designed 
a final survey for all regions; this survey was conducted in the first week of June and the results presented in this paper were gathered from this final survey.

Answers were translated then cleaned by standardizing spellings, removing filler words (and, or, those, the...), and linking words used in terms such as "no" and "income" before illustrating them in graphs or word clouds using MAXQDA. Analysis of quantitative data was coordinated in Berlin by two researchers and two student assistants using descriptive statistics (SPSS 25). In June and July 2020, the five research coordinators of the regions jointly analyzed and validated the local context in three in-depth discussions with a larger research consortium consisting of representatives of farmer organizations who worked in collaboration with researchers from the University of the Western Cape in South Africa, Universidade Eduardo Mondlane in Mozambique, Humboldt-Universität zu Berlin in Germany, and Coventry University in the UK.

\section{Results}

This section focuses on the information collected in the first week of June 2020. The findings are presented in three sub-sections. First, the challenges farmers experienced in their farming and marketing activities as a result of COVID-19 preventative measures are described. Second, the impacts on farmers' livelihoods and their communities are illustrated. Third, the perceived food price fluctuations and consequent changes in diets, food sources, and consumption patterns are presented. The section closes with description of the coping strategies that farmers developed.

Table 1 shows the number of respondents who were interviewed each week. The number of respondents snowballed as participating farmer co-researchers recruited additional farmers from their communities to participate; however, participation was somewhat restricted by the initial study design, in which farmers were required to use their own device to complete the survey. In the second week in April, the team in Maputo was not able to collect data due to the COVID-19 restrictions during that week.

Table 1. Number of respondents interviewed.

\begin{tabular}{cccccc}
\hline Time & Cape Town & Java & Maputo & Masvingo & Toraja \\
\hline April, week 1 & 18 & 41 & 10 & 10 & 11 \\
April, week 2 & 16 & 115 & - & 8 & 5 \\
April, week 3 & 23 & 157 & 20 & 43 & 8 \\
April, week 4 & 24 & 182 & 20 & 43 & 7 \\
June, week 1 & 52 & 114 & 28 & 53 & 209 \\
\hline
\end{tabular}

Table 2 gives more detailed description of the farmers who participated in the survey in June. Except for Java, the gender distribution is similar in all regions with about two thirds of the participants being women.

Table 2. Description of survey participants (June 2020).

\begin{tabular}{cccccc}
\hline $\mathbf{0}$ & Cape Town & Java & Maputo & Masvingo & Toraja \\
\hline No. of participants & $n=52$ & $n=114$ & $n=28$ & $n=53$ & $n=209$ \\
Female & $61.50 \%$ & $36.00 \%$ & $64.30 \%$ & $67.90 \%$ & $61.70 \%$ \\
Male & $38.50 \%$ & $64.00 \%$ & $35.70 \%$ & $32.10 \%$ & $38.30 \%$ \\
Age: & & & & & \\
25 and younger & $3.80 \%$ & $7.90 \%$ & $3.60 \%$ & $7.50 \%$ & $8.10 \%$ \\
$26-35$ & $23.10 \%$ & $21.90 \%$ & $10.70 \%$ & $18.90 \%$ & $21.10 \%$ \\
$36-45$ & $34.60 \%$ & $28.10 \%$ & $10.70 \%$ & $20.80 \%$ & $34.90 \%$ \\
$46-55$ & $17.30 \%$ & $24.60 \%$ & $35.70 \%$ & $26.40 \%$ & $21.50 \%$ \\
$56-65$ & $21.20 \%$ & $10.50 \%$ & $32.10 \%$ & $20.80 \%$ & $8.10 \%$ \\
Older than 65 & $0.00 \%$ & $7.00 \%$ & $7.10 \%$ & $5.70 \%$ & $6.20 \%$ \\
\hline
\end{tabular}


Table 2. Cont.

\begin{tabular}{cccccc}
\hline 0 & Cape Town & Java & Maputo & Masvingo & Toraja \\
\hline Educational level & & & & & \\
Primary & $36.50 \%$ & $21.90 \%$ & $39.30 \%$ & $25.50 \%$ & $29.70 \%$ \\
Secondary & $32.70 \%$ & $59.60 \%$ & $57.10 \%$ & $51.00 \%$ & $53.60 \%$ \\
Tertiary & $26.90 \%$ & $17.50 \%$ & $0.00 \%$ & $23.50 \%$ & $8.60 \%$ \\
None & $3.80 \%$ & $0.90 \%$ & $3.60 \%$ & $0.00 \%$ & $8.10 \%$ \\
\hline Rural/Urban & Urban & Rural & Peri-urban & Rural & Rural \\
\hline Governmental food & & & & & \\
assistance recipient? & & & & & \\
Yes & $1.90 \%$ & $47.40 \%$ & $0.00 \%$ & $0.00 \%$ & $74.20 \%$ \\
No & $98.10 \%$ & $52.60 \%$ & $100 \%$ & $100.00 \%$ & $25.80 \%$ \\
Governmental financial & & & & & \\
support recipient? & $11.50 \%$ & $15.80 \%$ & $0.00 \%$ & $1.90 \%$ & $63.50 \%$ \\
Yes & $88.50 \%$ & $84.20 \%$ & $100.00 \%$ & $98.10 \%$ & $36.50 \%$ \\
No & & & & \\
\hline
\end{tabular}

3.1. Farmers' Perceptions of the Impact of COVID-19 Interventions on Their Access to Their Farms and Markets

A striking observation is that in the countries that observed strict lockdown such as South Africa and Zimbabwe, small-scale farms were not regarded as "essential services" resulting in farmers being unable to access their farms and markets (see Figure 6). In South Africa, small-scale farmers did not receive permits to continue their farming activities [36]. In Zimbabwe, 32 percent of the surveyed farmers reported difficulties accessing their farms. In contrast, in the rest of the study sites, small-scale farms were regarded as essential and almost all participants could access their farms.

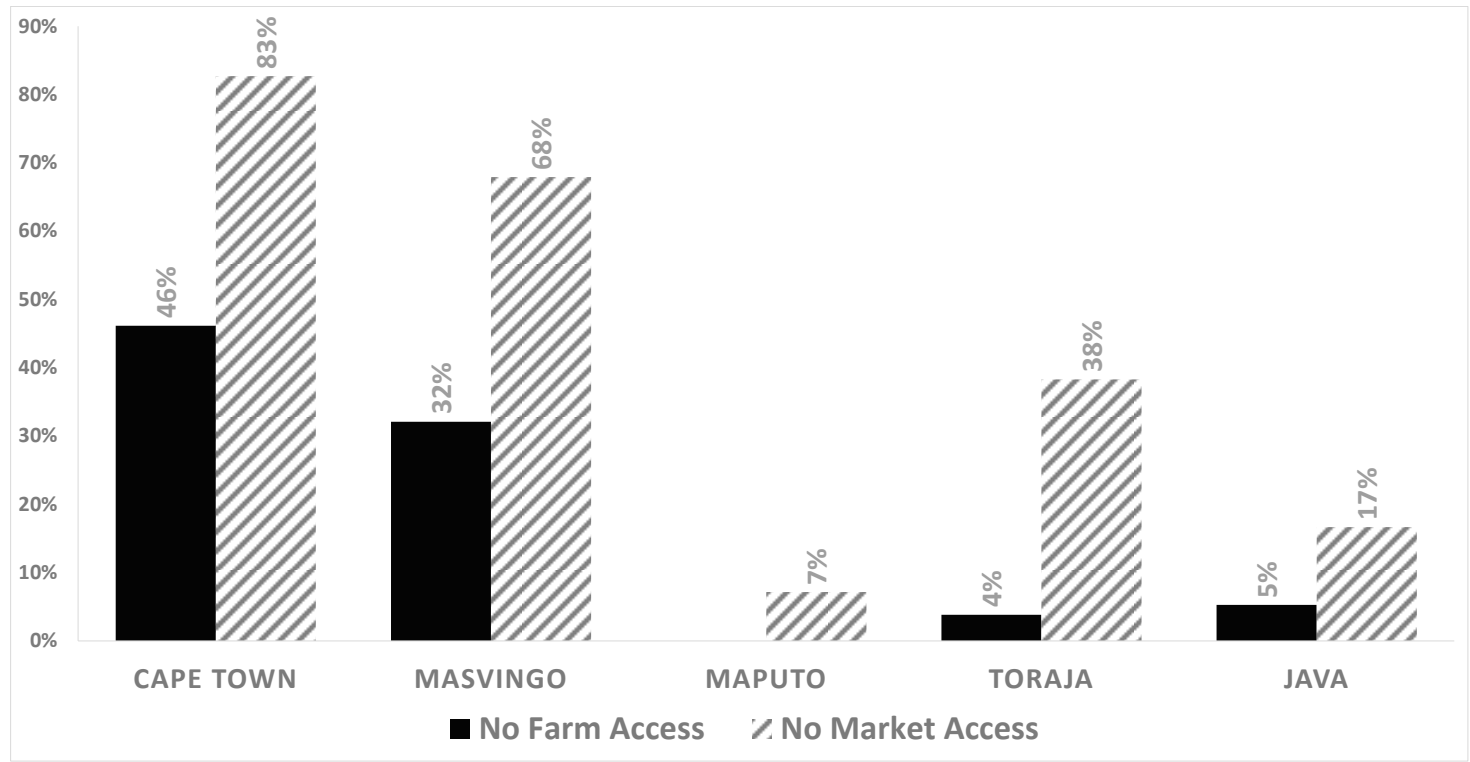

Figure 6. Proportion of respondents reporting being unable to access their farm and market in June 2020. Cape Town $(n=52)$, Masvingo $(n=53)$, Maputo $(n=28)$, Toraja $(n=209)$, and Java $(n=114)$.

A similar dynamic was observed in farmers' ability to sell their products. Cape Town and Masvingo farmers were the most affected by market disruptions, making it impossible to sell their produce. Farmers in Maputo and in the two Indonesian regions were the least affected by marketing disruptions as they continued to sell to local communities; in fact, local demand increased as food imports from South Africa were restricted. Figure 7 shows the main reasons farmers could not access markets for their goods. 


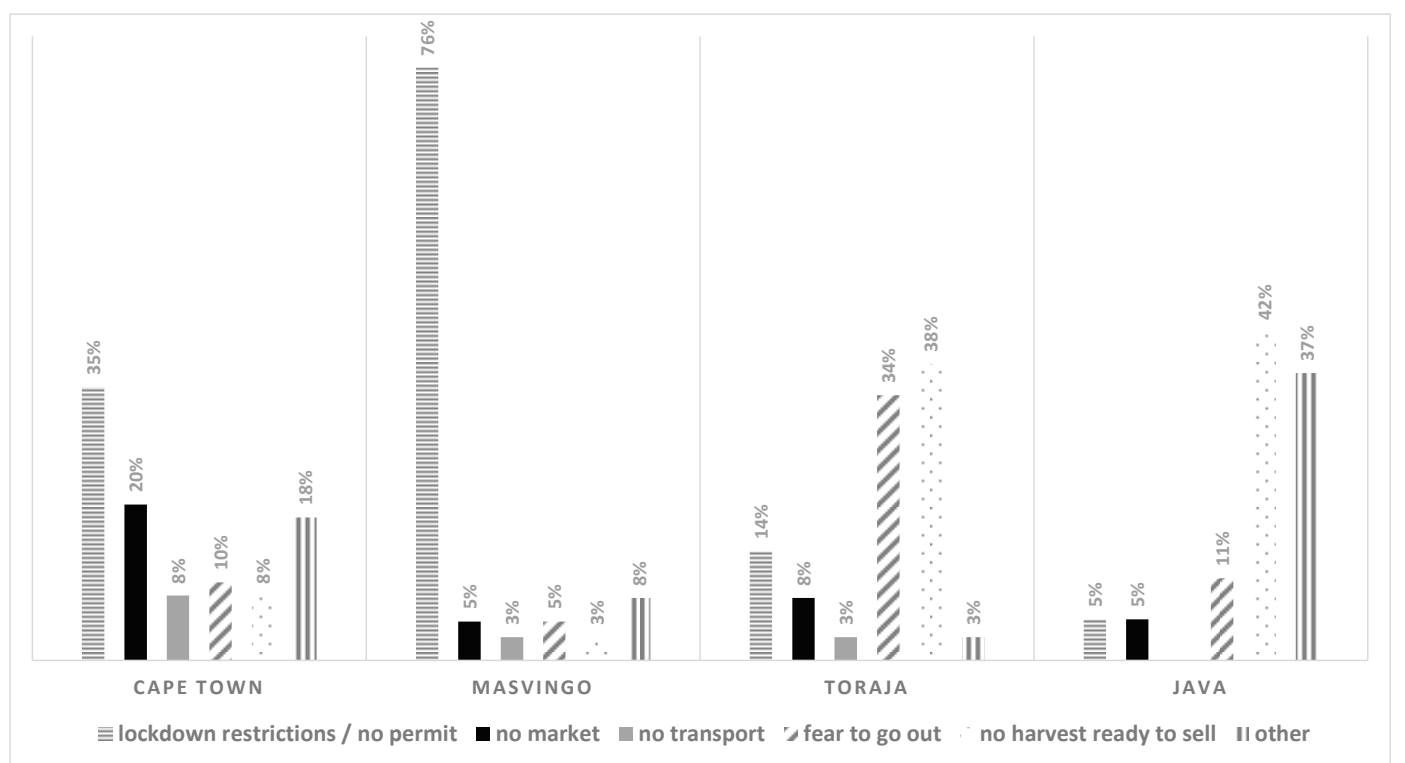

Figure 7. Main reasons farmer respondents reported being unable to sell their crops in June 2020. Note that only those respondents who could not sell their crops as a result of COVID-19 restrictions are graphically represented. Cape Town $(n=43)$, Masvingo $(n=36)$, Maputo $(n=2)$, Toraja $(n=81)$, and Java $(n=19)$.

As a result, many farmers sought new markets during lockdown (see Figure 8). In Cape Town, township communities and neighborhoods were the main markets for farmers during the lockdown as well as, to a lesser extent, restaurants and vegetable box schemes. Local community markets were viewed as important by more women farmers ( 47 percent) than men farmers ( 20 percent) before lockdowns. In Maputo, local markets via intermediaries made up more than 90 percent. In Toraja, the farmers market was the primary market, followed by local communities. In Java, intermediaries represented one third of the market, with local communities at 26 percent, and farmers markets at 23 percent.

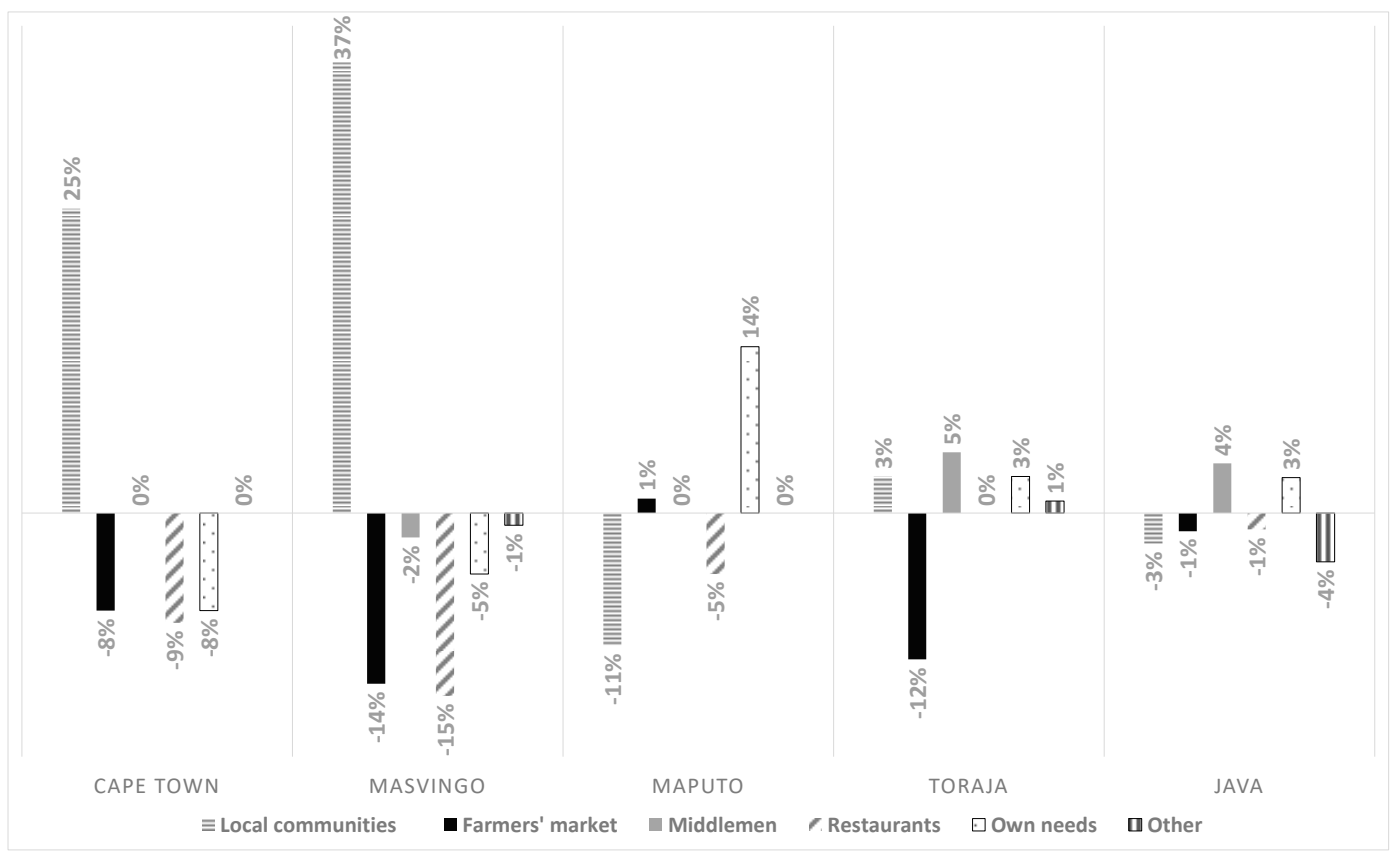

Figure 8. Percent change in frequency of accessing particular markets in response to COVID-19 restrictions (June 2020). The graph is based on those respondents who could sell their crops despite COVID-19 restrictions. Cape Town $(n=10)$, Masvingo $(n=18)$, Maputo $(n=26)$, Toraja $(n=128)$, and Java $(n=95)$. 
In Cape Town, farmer respondents reported selling their products to local communities $25 \%$ more frequently to compensate for the loss of demand from and sales to restaurants and high-end markets due to COVID-19 restrictions. Similarly, urban farmers responded to the temporary cessation of NGO retail markets by establishing neighborhood WhatsApp marketing groups and initiating word-of-mouth advertising for their produce. Masvingo followed a similar pattern with farmers actively compensating for the reduction of sales to restaurants, high-end markets, and farmers markets by marketing to local communities 37 percent more often. As in Cape Town, farmers used their produce to meet their own needs 5 percent less frequently after the lockdowns. In Maputo, the inverse situation was reported, with farmers reporting marketing to local communities 11 percent less frequently and own consumption increasing by 14 percent. In Toraja, minor changes were reported, with produce largely used for own consumption and a 3 percent increase in sales to local communities. Java experienced only minor changes, with a decrease in sales to local communities of 3 percent and an increase in produce used for own consumption of 3 percent.

\subsection{Farmers' Perceptions of the Impact of COVID-19 Interventions on Their Communities}

Community-level impacts of either lockdown, states of emergency, or large-scale social restrictions were documented through open-ended questions to small-scale farmers. Their responses are displayed visually in Figure 9, which shows the most frequently mentioned answers in the largest font size.

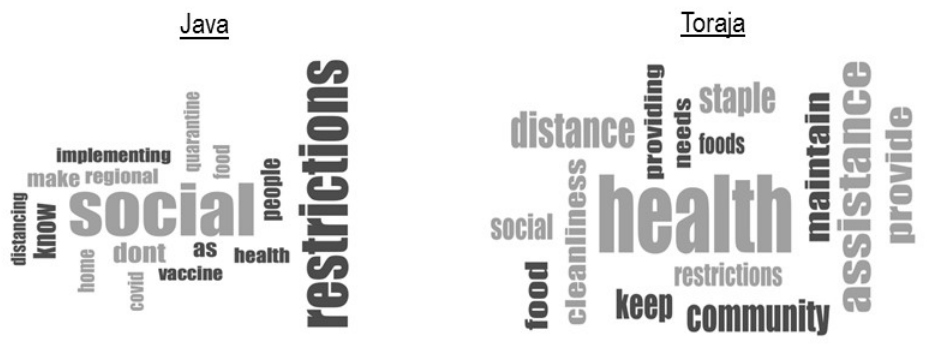

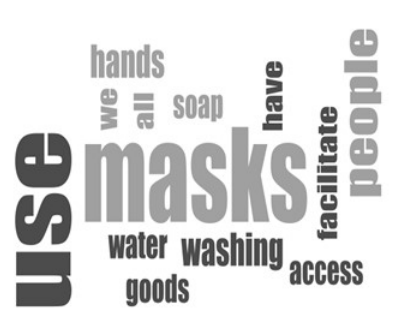

Maputo

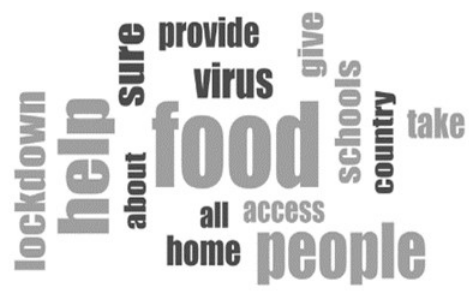

Cape Town

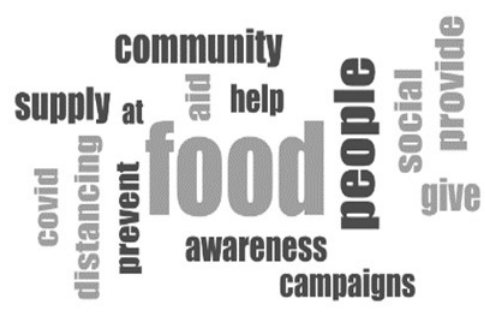

Masvingo

Figure 9. Word map depicting small-scale farmers' perceptions of the main impact of COVID-19 interventions on local communities in June 2020. Cape Town $(n=52)$, Masvingo $(n=53)$, Maputo $(n=28)$, Java $(n=114)$, Toraja $(n=209)$.

In Cape Town, food insecurity and hunger were mentioned by farmers as the main impacts of the lockdown. Farmers further observed a rise in poverty and unemployment, leading to hunger and higher levels of crime. In Masvingo, farmers documented experiencing hunger and food insecurity due to shortages of food and spiking food prices. In their communities, market closures, economic recession, and more thefts were also documented. Food was mentioned by farmers as their most significant need, followed by creating awareness about hygiene measures and materials to battle COVID-19.

In Maputo, farmers perceived the primary impact of COVID-19 interventions to be the lack of customers, which limited their income. They also mentioned the closure of businesses, shops, schools, places of worship, and the limited movement of people (particularly not being able to visit family). Farmers felt COVID-19 control strategies should focus on reduction of transmission including 
widespread mask use and public education on transmission reduction through simple interventions such as handwashing.

In Java, farmers documented difficulties travelling to other regions of the country or visiting relatives outside Java. Migrant workers were unable to return home or have their relatives return, especially impacting Eid al-Fitr celebrations. Other reported impacts were related to school closures; reductions in income and work; and reductions in community, social, and religious interactions. This particularly affected musyawarah, which is a form of consensus building resulting from prolonged discussions and sharing of ideas and views during a meeting.

In Toraja, farmers were concerned about not being able to go outside, perform their usual activities, meet their neighbors and families, and visit places of worship. They reported feeling frustrated by being barred from religious gatherings, as they perceived religious activities as playing a significant role in the impact of COVID-19.

\subsection{Farmers' Perceptions of the Impact of COVID-19 Interventions on Their Diets}

COVID-19 interventions profoundly impacted farmers' eating habits. This section describes how small-scale farmers responded to food scarcity and price increases resulting from COVID-19 interventions (Figure 10).

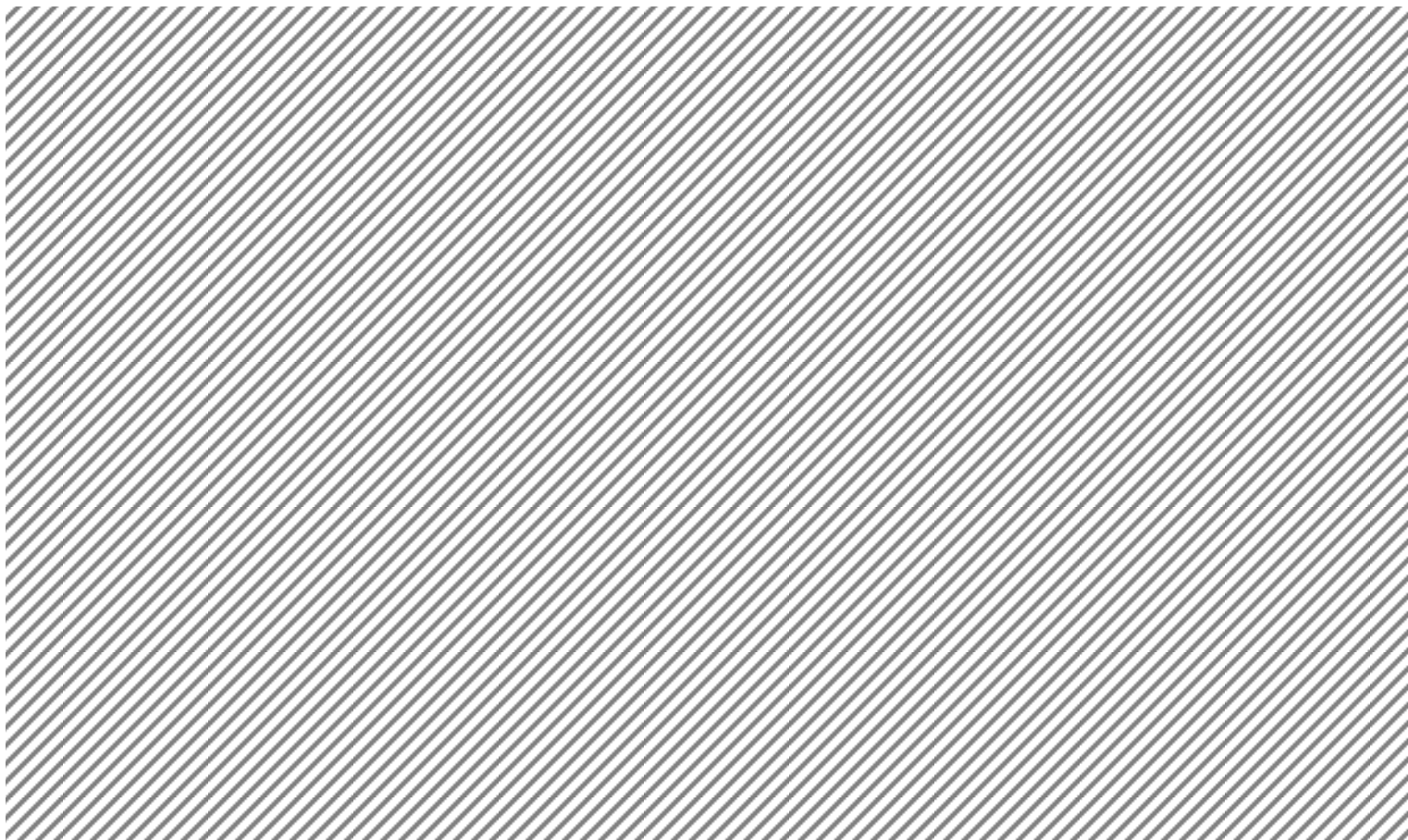

Figure 10. Farmers' perceptions of food availability and affordability in June 2020. Cape Town $(n=52)$, Masvingo $(n=53)$, Maputo $(n=28)$, Java $(n=114)$, Toraja $(n=209)$.

Farmers further reported on perceived food price development (Figure 11) and changes in household diets (Figure 12). 


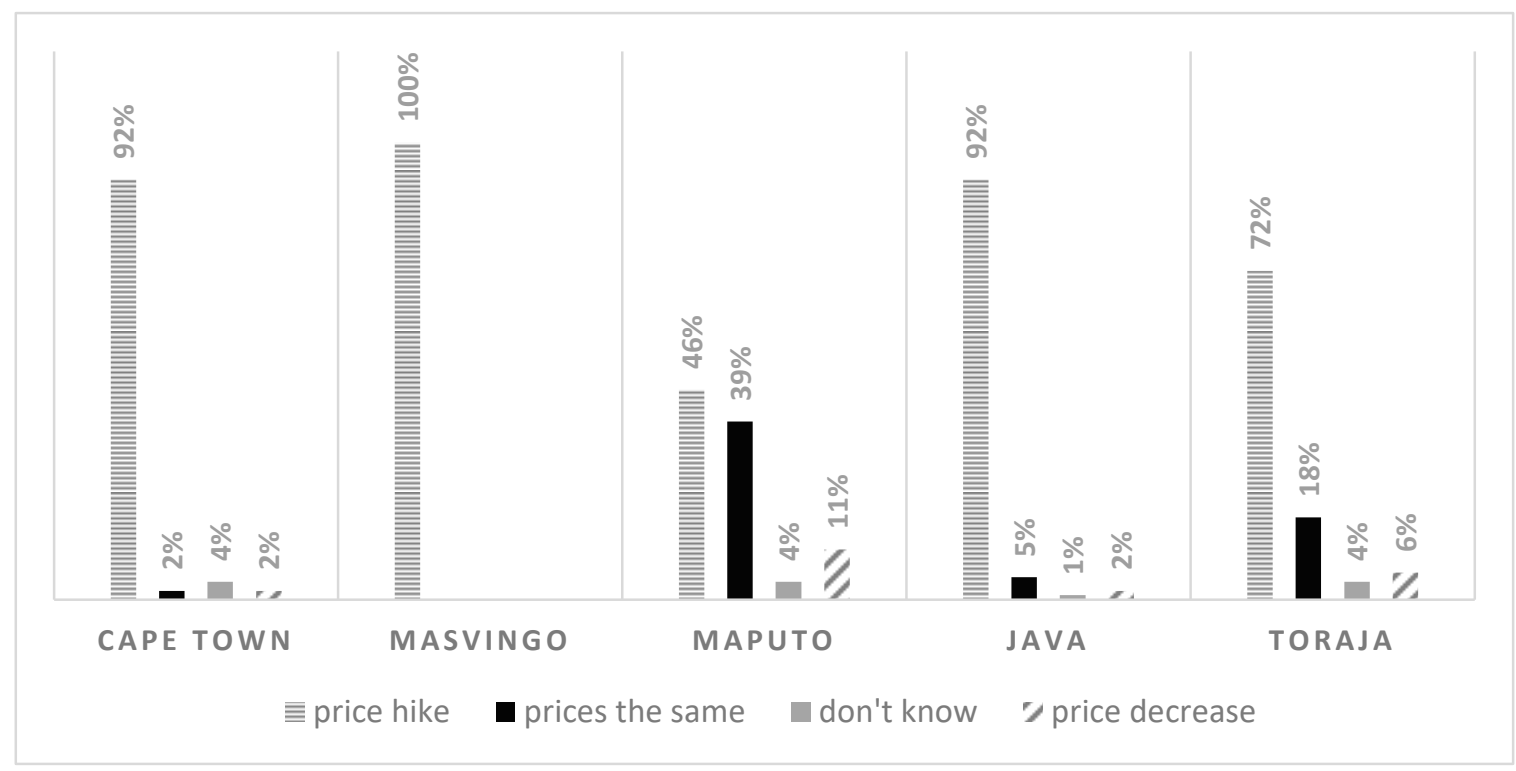

Figure 11. Farmers' perceptions of food price changes due to COVID-19 interventions (June 2020). Cape Town $(n=52)$, Masvingo $(n=53)$, Maputo $(n=28)$, Java $(n=114)$, Toraja $(n=209)$.

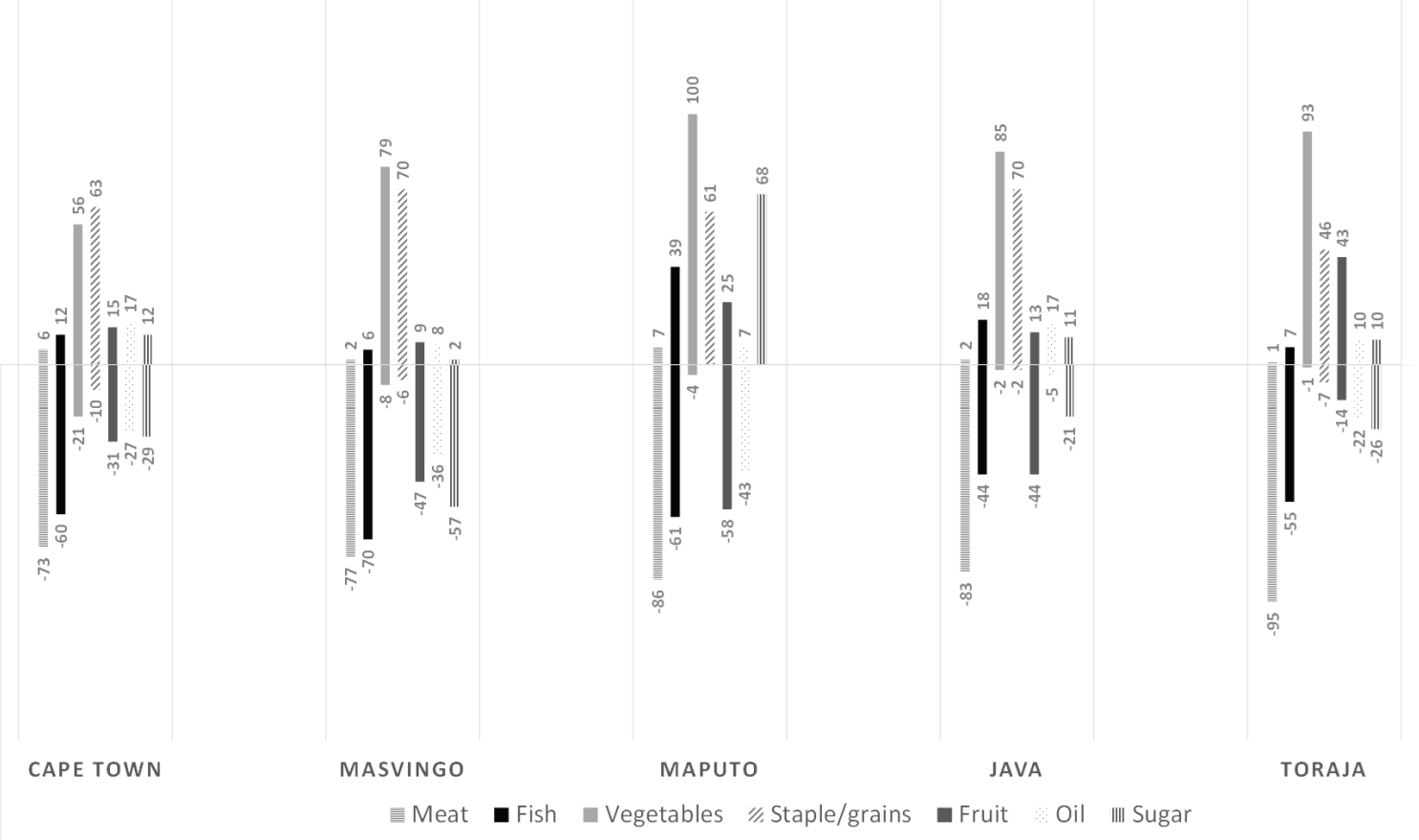

Figure 12. Percentage of respondents who reported more/less consumption of selected food products in June 2020. Cape Town $(n=52)$, Masvino $(n=53)$, Maputo $(n=28)$, Java $(n=114)$, Toraja $(n=209)$. Source: June 2020.

In Cape Town, reports of increases in the prices of meat after COVID-19 interventions were implemented far exceeded increases in other food prices. Consequently, a decrease in meat consumption was reported by 70 percent of the sample. Similarly, other surveyed regions reported that consumption of vegetables and grains increased during COVID-19 intervention implementation, with 72 percent of women reporting eating more staples and grains compared to 50 percent of men. Overall, 85 percent of farmers documented that price changes limited their ability to acquire food. With lockdowns, 6 percent and 12 percent of farmers reported sourcing food less frequently from local vendors and supermarkets, 
respectively. The number of farmers who sourced food from soup kitchens and donations from family and friends increased by 8 percent and 9 percent, respectively, with more women than men reporting receiving food donations from family and friends (31 and 15 percent).

In Masvingo, over 85 percent of farmers reported food prices had increased during COVID-19 intervention implementation, which coincides with an already-critical period of economic crisis and hyperinflation. Farmer respondents reported eating less of most foods, except vegetables and grains. Again, results were gender specific, with 56 percent of women reporting they consumed less fruit versus 31 percent of men and 75 percent of women stating that they consumed more staples and grains compared to 56 percent of men. Overall, 92 percent of farmers reported that price changes limited their ability to acquire food. Remarkably, farmers shopped 12 percent and 5 percent less frequently from traditional food markets and supermarkets, preferring to source food from their own gardens and farms 19 percent more frequently.

Maputo farmers saw their ability to acquire food during lockdowns as extremely diminished, with 96 percent of farmers reporting limitations. Sugar was reported as the product with the most drastic price change, a predictable outcome of the limitation of South African imports. Local sugar producers took advantage of this situation and increased prices. Farmers also reported an increase in their grain consumption. As markets were disrupted, consumption in supermarkets and local markets decreased by 3 percent and 5 percent, respectively, during the state of emergency. Consumption from their own farms or gardens increased by 3 percent while receiving food from neighbors and donations from the community increased by 5 percent.

Unlike all southern African study areas, the Indonesian government distributed food aid to Indonesians, with 74 percent of Toraja farmers and 47 percent of Java farmers reporting they received government food parcels. Lower participation in Java was due to limited supplies spread over a higher population in Java. Despite this, farmers reported that price increases for all foods surpassed 50 percent, with fruit price increases reported by 94 percent of respondents. The consumption fell sharply as a result, which was similar for fish and meat. These food groups are mostly distributed by brokers and retailers and rarely sold by farmers themselves. Over the study period, Javanese farmers reported using traditional food markets like local vendors and farmers markets 5 percent less frequently each.

Similarly, in Toraja, sugar prices showed an increase of almost 90 percent, followed by meat and grains. Household dietary consumption of meat and fish decreased considerably, while increased vegetable consumption was reported by 93 percent of respondents. Toraja was the only region where fruit consumption increased. A large variety of fruits are grown in Toraja, and access was possible from own farms or by swapping fruits with neighbours. COVID-19 restrictions limited 76 percent of farming households' ability to acquire food. In Toraja, respondents reported shopping for food in traditional markets 10 percent less often, preferring to source food directly from farmers' gardens 7 percent more often.

\subsection{Farmers' Perceptions of the Impact of COVID-19 Interventions on Their Food Security}

Increasing prices and inaccessible food led to changes in farmers' diets (Figure 13). The following section compares the five case study areas.

Gender differences with regard to limiting quantity of food were pronounced in Cape Town and Masvingo. In Cape Town, 59 percent of women reported that they had limited the quantity of food they consumed daily or often, while this was reported by 30 percent of men. In Masvingo, 64 percent of women limited their portion size at mealtimes daily or often, versus 37 percent of men. In Masvingo, 61 percent of women reported reducing the number of meals consumed in a day often, while this was the case for 37 percent of men. 37 percent of men reported eating only one meal per day during this period versus 11 percent of women. 


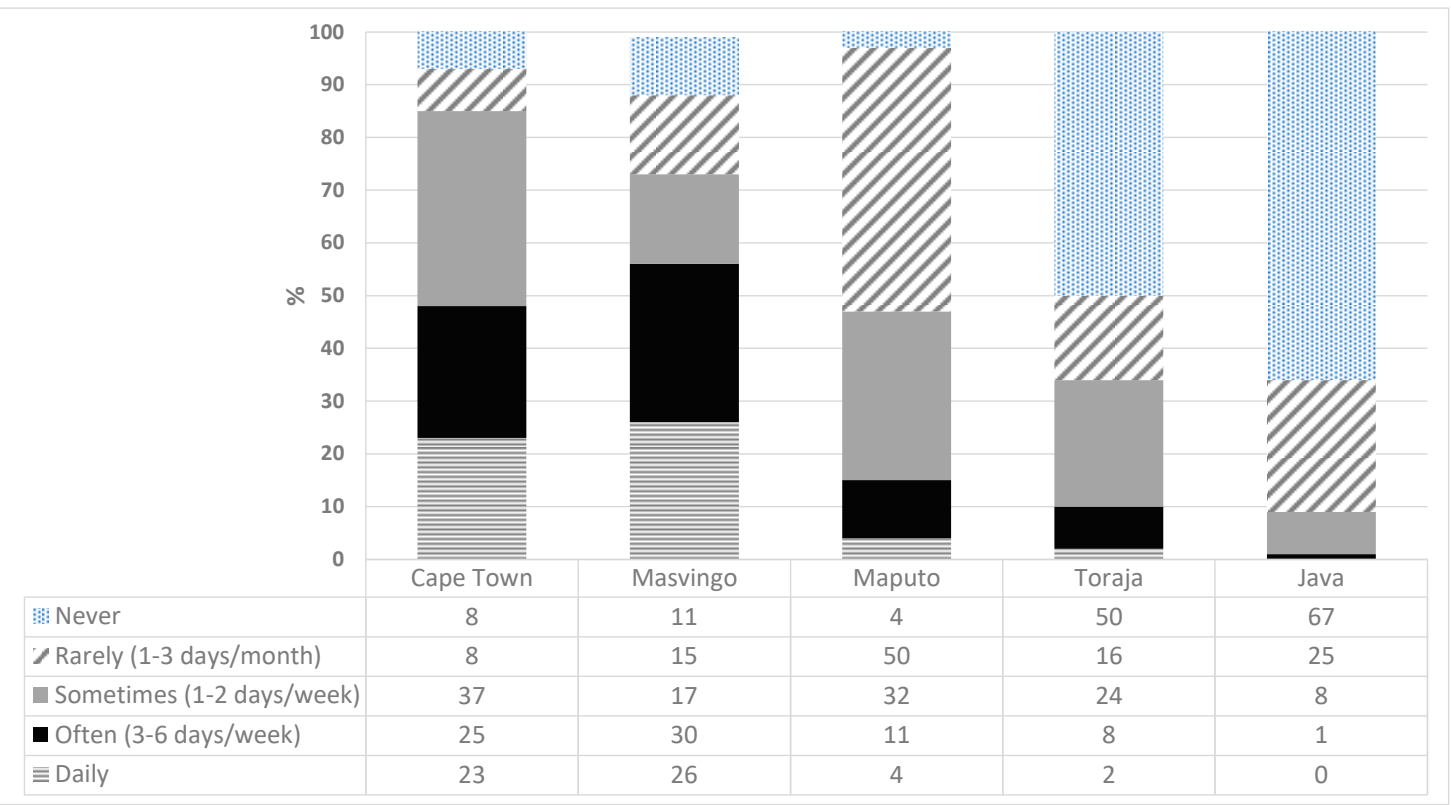

Figure 13. How often farming households limited food consumption in June 2020. Cape Town $(n=52)$, Masvingo $(n=53)$, Maputo $(n=28)$, Toraja $(n=209)$, and Java $(n=114)$.

In Masvingo, 39 percent of women reported they had to make decisions between having food or meeting other needs daily or often, while this was the case for 69 percent of men. The other regions did not show significant differences in the replies of women farmers. However, it is interesting to note that in Cape Town and Masvingo where strict lockdowns necessitated home schooling, additional financial needs for electricity and mobile phone data created a severe conflict of interest with buying of food (Figure 14).

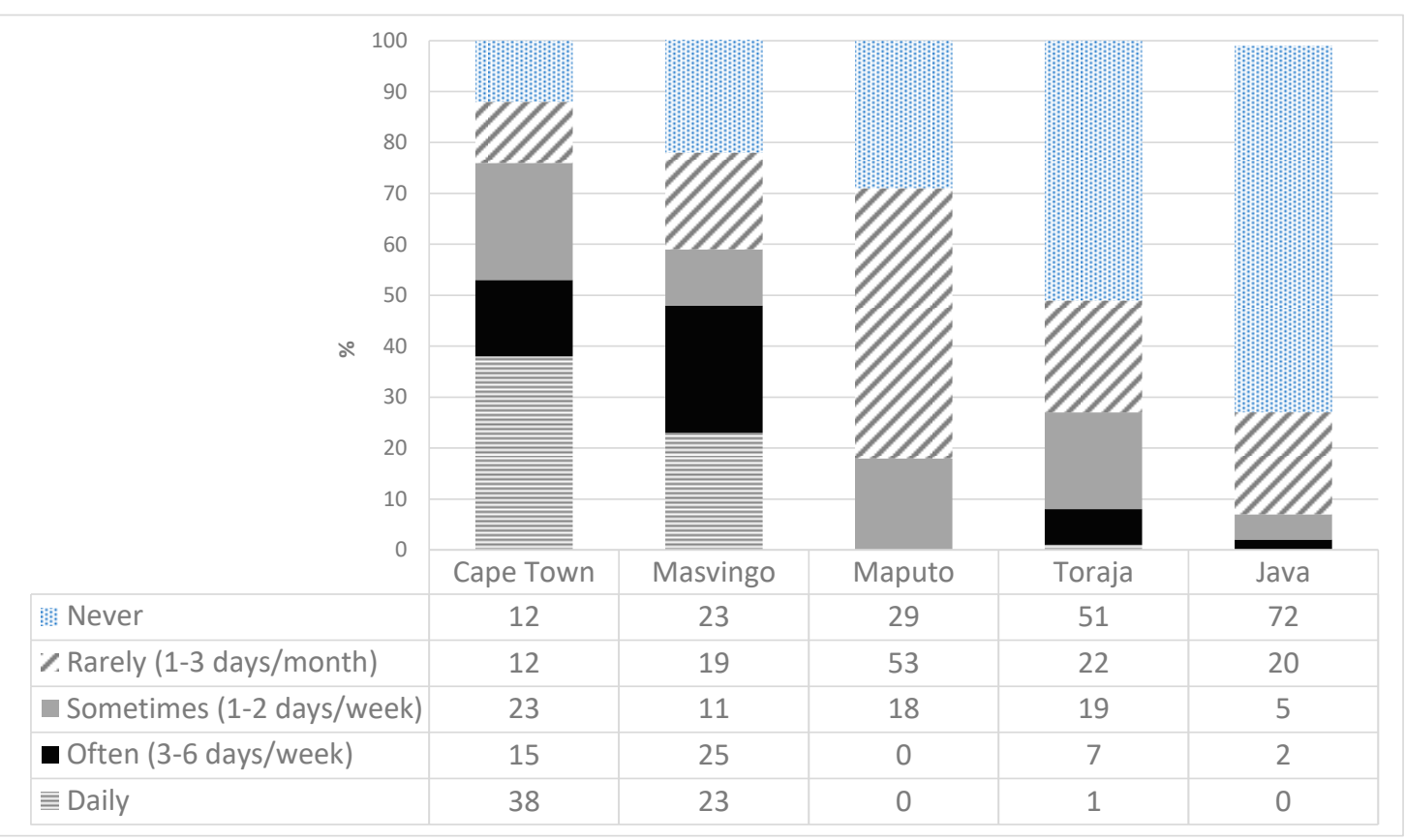

Figure 14. How often farming households decided between food and other needs in June 2020. Cape Town $(n=52)$, Masvingo $(n=53)$, Maputo $(n=28)$, Toraja $(n=209)$, and Java $(n=114)$.

Buying food on credit when financial means were scarce was a common coping strategy in Cape Town even before the COVID-19 measures and has probably been reinforced by the rise in prices 
(Figure 15). In Maputo, farmers report that this is usually not done as a matter of principle, because it damages the family reputation.

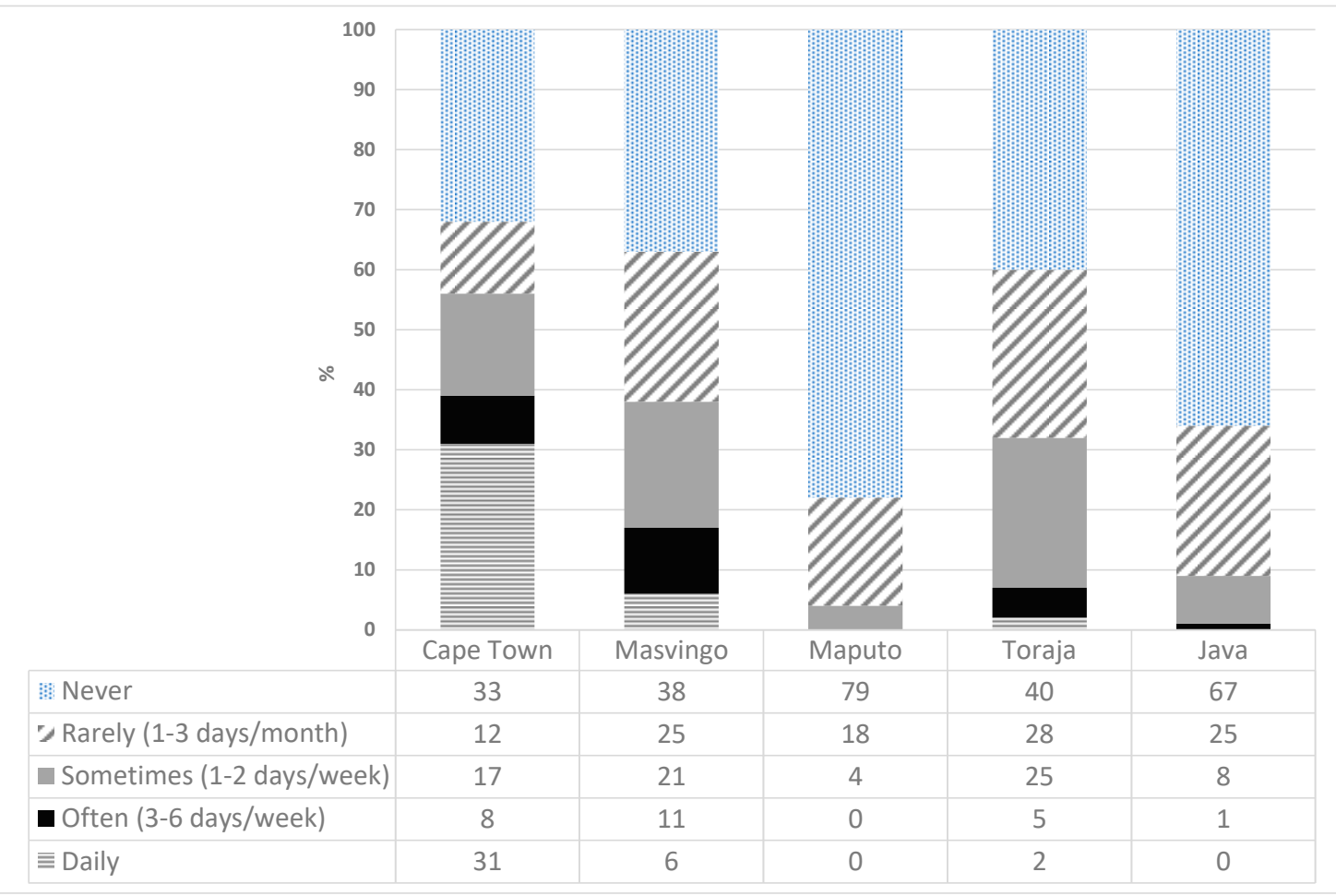

Figure 15. How often households purchased food on credit in June 2020. Cape Town $(n=52)$, Masvingo $(n=53)$, Maputo $(n=28)$, Toraja $(n=209)$, and Java $(n=114)$.

\subsection{Coping Strategies Employed by Farmers in Response to the Impact of COVID-19 Interventions}

A central question in this project was to understand and document coping strategies developed by farmers (see Table 3). We hypothesized women are the drivers of change and show a higher rate of adaptive capacity during the COVID-19 crisis and develop more and diverse coping strategies and solutions.

Almost half of the farmers in Toraja developed solutions to improve their food security during the pandemic. Of these, 61 percent were women. Generally, farmers mentioned that they started vegetable gardens $(62 \%)$, spent less $(11 \%)$, and changed their diets $(11 \%)$. Among those farmers who developed solutions to improve their food situation, 88 percent reported they achieved those solutions in cooperation with their family and 19 percent with their neighbors. Government assistance was mentioned by only 3 percent of farmers.

In Masvingo, 30 percent of farmers reported developing solutions and 81 percent of these were women. Half of the solutions were related to growing more food by expanding the areas under cultivation, for example 19 percent mentioned they "rely on their own produce", 13 percent mentioned waged piece work, and 13 percent mentioned starting small income-generating projects. The family was mentioned by 75 percent of respondents to have been the main supporter of solutions, followed by the communities, mentioned by 13 percent. 
Table 3. Coping strategies used by farmers in response to COVID-19 restrictions (June 2020).

\begin{tabular}{|c|c|c|c|c|}
\hline & Cape Town & Masvingo & Java & Toraja \\
\hline $\begin{array}{c}\text { Percentage of } \\
\text { farmers who } \\
\text { developed a coping } \\
\text { strategy }\end{array}$ & $27 \%$ & $30 \%$ & $14 \%$ & $49 \%$ \\
\hline $\begin{array}{c}\text { Percentage of } \\
\text { female farmers } \\
\text { who developed } \\
\text { coping strategies }\end{array}$ & $57 \%$ & $81 \%$ & $37 \%$ & $61 \%$ \\
\hline $\begin{array}{l}\text { Person/organization } \\
\text { who assisted } \\
\text { respondent } \\
\text { develop coping } \\
\text { strategy }\end{array}$ & $\begin{array}{c}64 \% \text { family } \\
28 \% \text { community } \\
7 \% \text { Cape Town } \\
\text { Action Network } \\
\text { (CAN) }\end{array}$ & $\begin{array}{l}93 \% \text { family } \\
6 \% \text { farmers }\end{array}$ & $\begin{array}{c}88 \% \text { family } \\
12 \% \text { community }\end{array}$ & $\begin{array}{c}85 \% \text { family } \\
12 \% \text { community * } \\
3 \% \text { government }\end{array}$ \\
\hline Type of solutions & $\begin{array}{l}\text { Sharing food in } \\
\text { community via } \\
\text { WhatsApp } \\
\text { (Communities } \\
\text { organized } \\
\text { themselves in } \\
\text { neighborhood } \\
\text { WhatsApp groups } \\
\text { to swap food) } \\
\text { established soup } \\
\text { kitchens } \\
\text { limited food intake } \\
\text { bought food on } \\
\text { credit } \\
\text { grew more food }\end{array}$ & $\begin{array}{l}\text { grew more food, } \\
\text { expanded garden } \\
\text { exchanged food } \\
\text { within community }\end{array}$ & $\begin{array}{l}\text { grew more food } \\
\text { healthy diets } \\
\text { (Respondents } \\
\text { reported they } \\
\text { aimed to } \\
\text { strengthen their } \\
\text { immune system by } \\
\text { eating more } \\
\text { vegetables in fear } \\
\text { of COVID-19) } \\
\text { changed diet and } \\
\text { bought cheaper } \\
\text { foods } \\
\text { spent less money } \\
\text { on food } \\
\text { increased hygiene } \\
\text { and safety }\end{array}$ & $\begin{array}{l}\text { grew more food } \\
\text { healthy diets } \\
\text { changed diet and } \\
\text { bought cheaper } \\
\text { foods } \\
\text { spent less money } \\
\text { on food } \\
\text { increased hygiene } \\
\text { and safety }\end{array}$ \\
\hline
\end{tabular}

* Community is interpreted as churches, neighbors, and community. Respondents: Cape Town $(n=14)$, Masvingo $(n=16)$, Java $(n=16)$, Toraja $(n=103)$. In Maputo, only one person reported developing a solution (male farmer, starting to sell crops to neighbors); due to the small sample, his responses are not considered in the table above.

Similarly, 27 percent of Capetonian farmers said they developed coping mechanisms during the crisis and more than half (53\%) reported soup kitchens as a major solution, probably because soup kitchens are promoted by many NGOs in Cape Town. Growing their own food and changing eating patterns were both mentioned by 13 percent of respondents. 50 percent reported their family was the main contributor to these solutions, followed by their community $(43 \%)$ and places of worship $(7 \%)$.

A different situation was reported in Java, where only 16 respondents-corresponding to 14 percent of the sample-answered the survey question on solutions that helped them cope with the changed situation. They may not have answered this question either because they did not develop solutions or because they did not recognize their coping strategies as solutions. Diet management and growing vegetables in the yard was mentioned by 36 percent of respondents. The family was recognized as the primary contributor to achieving solutions by 61 percent, followed by neighbors (mentioned by 28 percent of respondents).

In Maputo, one farmer reported developing solutions, constituting 4 percent of the sample.

\subsection{Visioning Exercise: What Would Farmers Do to Address COVID-19 If They Were in Political Power?}

The co-researchers applied another approach to assess the pandemic's impact on farming activities, farmers' livelihoods, and farmers' frustrations during the initial phase of the pandemic: they asked farmers the hypothetical question, "If you were 'the Minister of COVID-19' in your country, what priority policy action would you take to handle the pandemic in your community?" Strikingly, in all five regions, 
there were very few differences between the stated visions of women and men. The main priorities were food relief and the impeding hunger crisis in Cape Town and Masvingo; the fear of infections and demand for protective equipment such as face masks and soap in Maputo; and social restrictions, border closures, and health system support in Indonesia, where their opinions are influenced by their close proximity to China and prior experience with SARS. The word clouds below (Figures 16-20) illustrate farmers' visions in the five regions.

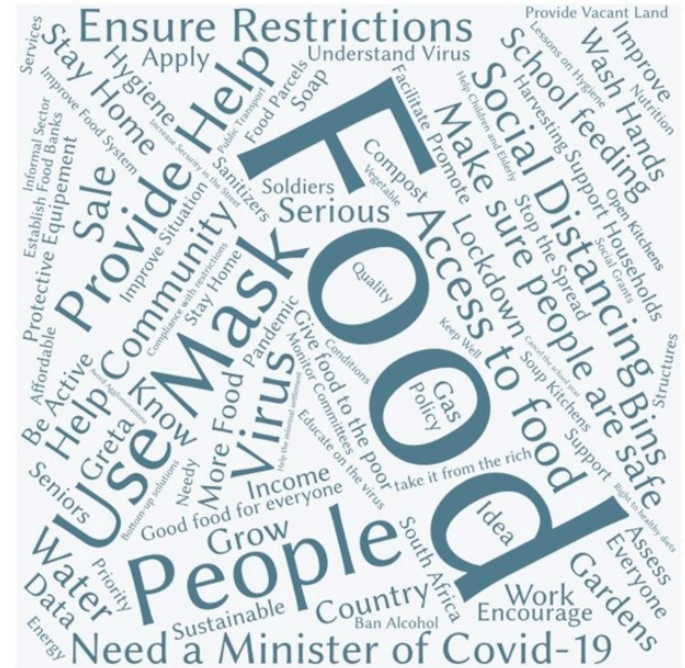

(a)

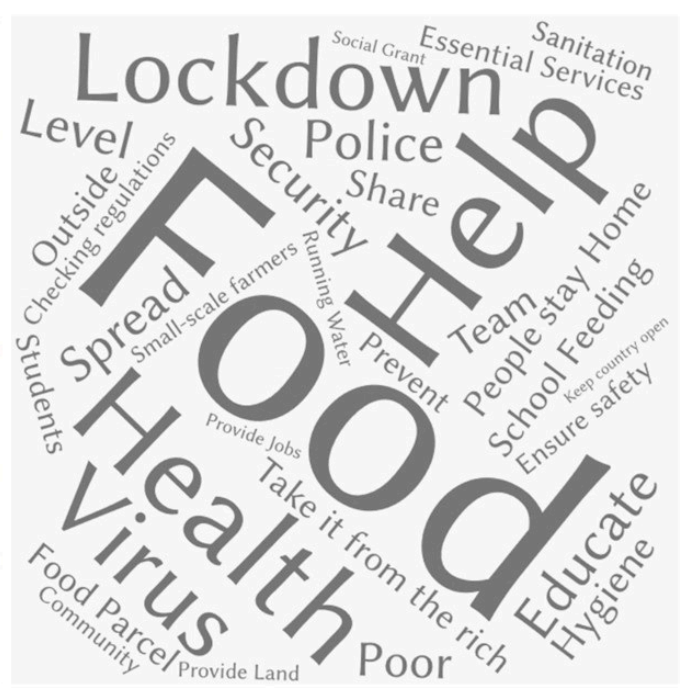

(b)

Figure 16. Cape Town: Small-scale farmers' ideas on national priorities to control and mitigate the impacts of COVID-19. Note: (a) women farmers, (b) men farmers, $n=52$, June 2020.

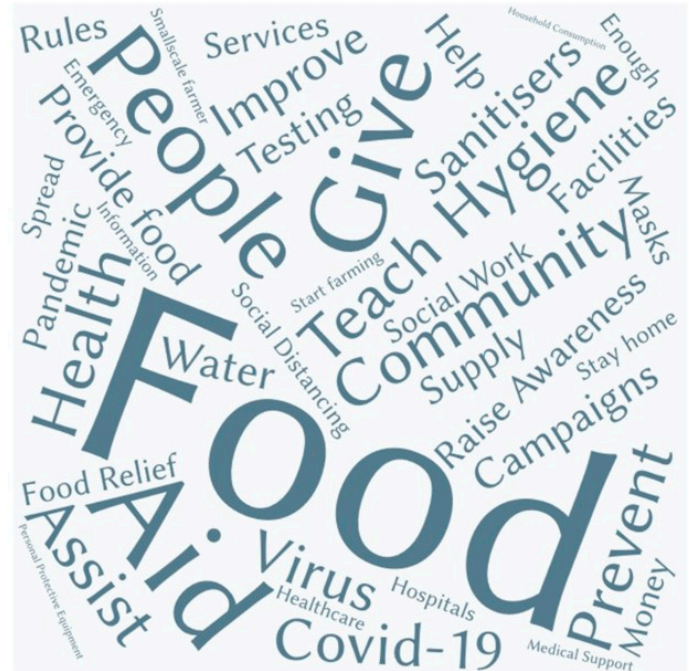

(a)

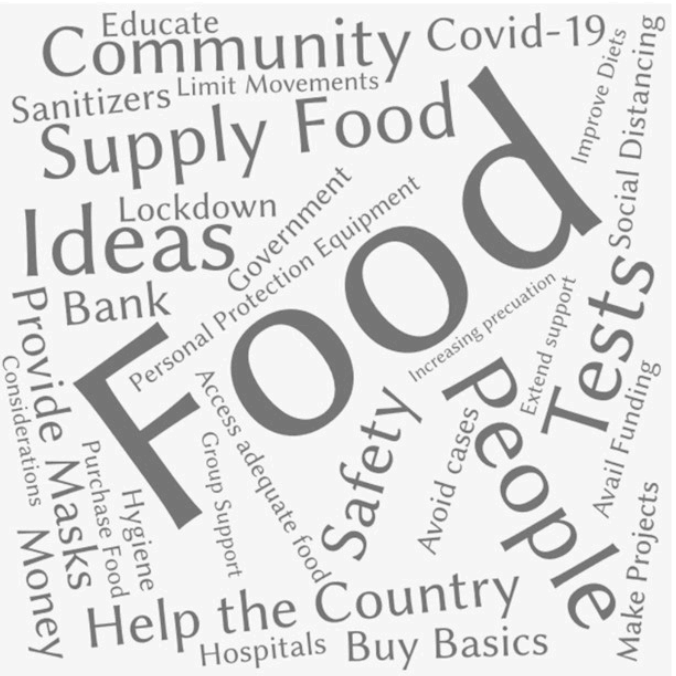

(b)

Figure 17. Masvingo: Small-scale farmers' ideas on national priorities to control and mitigate the impacts of COVID-19. Note: (a) women farmers, (b) men farmers, $n=53$, June 2020. 


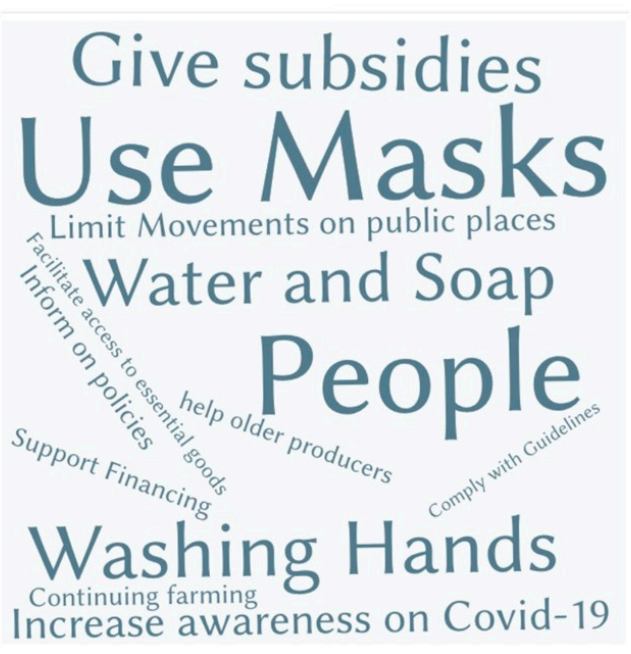

(a)

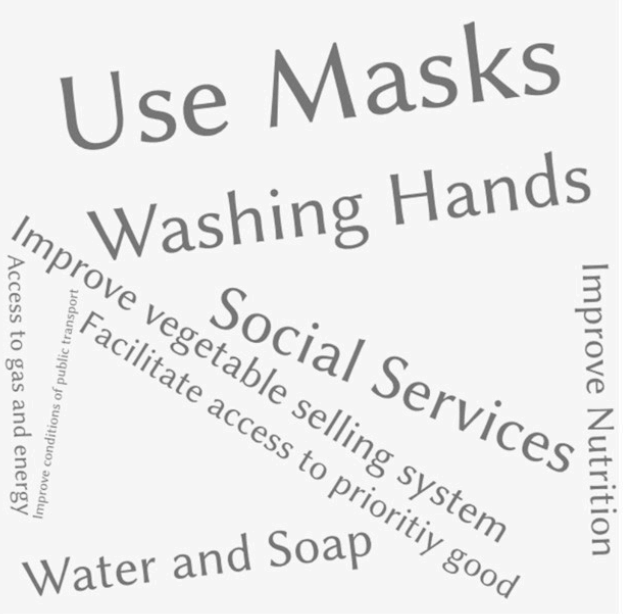

(b)

Figure 18. Maputo: Small-scale farmers' ideas on national priorities to control and mitigate the impacts of COVID-19. Note: (a) women farmers, (b) men farmers, $n=28$, June 2020.

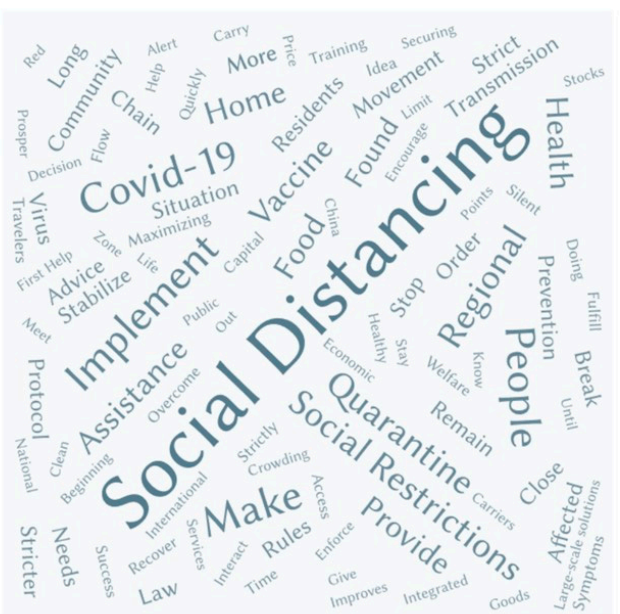

(a)

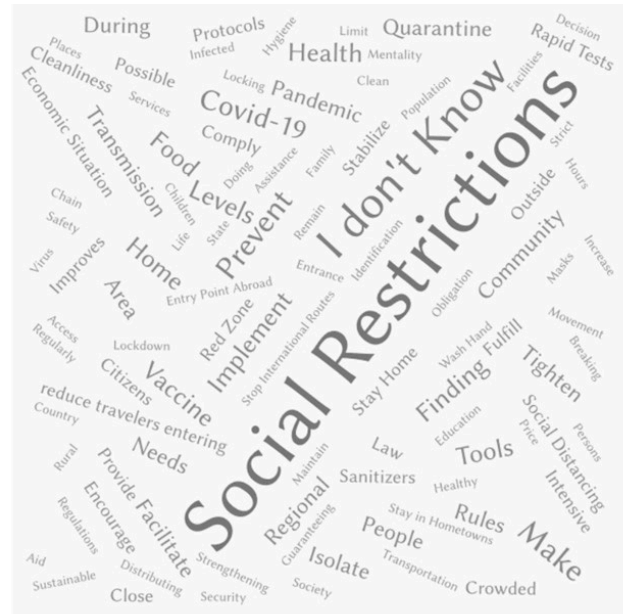

(b)

Figure 19. Jav: Small-scale farmers' ideas on national priorities to control and mitigate the impacts of COVID-19. Note: (a) women farmers, (b) men farmers, $n=114$, June 2020.

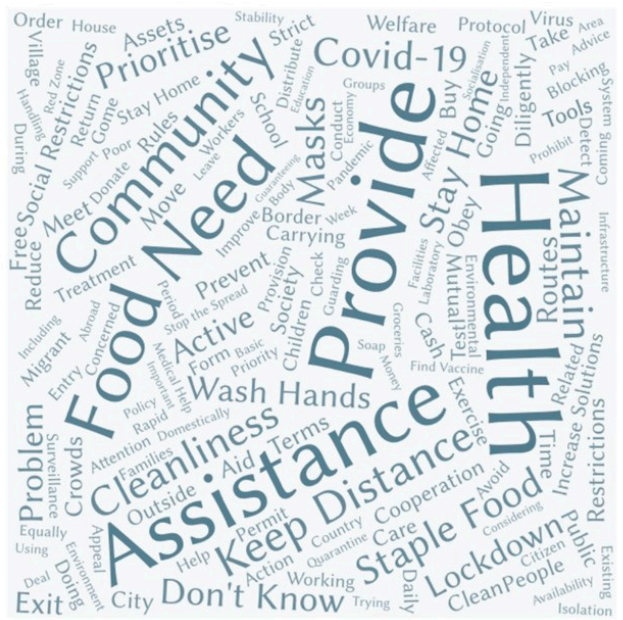

(a)

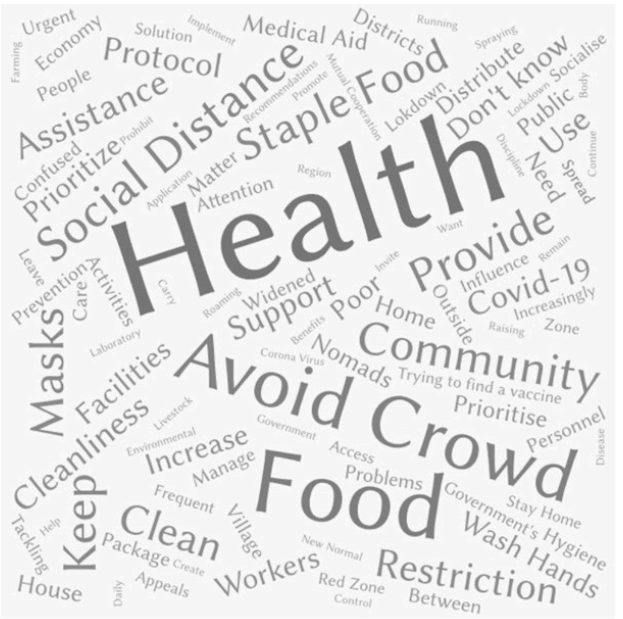

(b)

Figure 20. Toraja: Small-scale farmers' ideas on national priorities to control and mitigate the impacts of COVID-19. Note: (a) women farmers, (b) men farmers, $n=209$, June 2020. 


\section{Discussion}

\subsection{Farmers' Resilience to Cope with COVID-19 Measures}

This paper seeks to show how small-scale farmers have responded to the COVID-19 crisis and their resilience to related stresses. Although the respective study sites differ fundamentally due to their historical, geographic, climatic, and socio-economic characteristics, there are commonalities. Central experiences of farmers in Cape Town and Masvingo during the crisis were hunger and lack of food, as the word cloud illustrations of qualitative responses show. At the same time, farmers in both areas struggled to access their farms, produce food, and access informal food markets. In Mozambique and Indonesia, health-related issues and the restrictions imposed by social distancing measures were of major concern for farmers. In Indonesia and Maputo, food insecurity for farmers was not as important as in Cape Town and Masvingo.

Across all regions, the study showed that small-scale farmers rely primarily on social capital to cope with the COVID-19 crisis, i.e., their coping strategies were mostly developed within their immediate family, farming networks, or neighborhoods. The crisis also shows that small-scale farmers in Southern Africa are not yet prepared for supplementing local communities as farmers have little transformative capacity and agency to establish localized food systems that provide sufficient food for communities. The situation in Indonesia demonstrates that well-organized, small-scale farmer groups are part of the informal economy and are highly acknowledged actors within localized food systems, and that these informal local food systems are able to perform with resilience to shocks when larger food supply chains are severely disrupted or break down.

To make food systems more resilient in the long term, multiple stress factors such as the impacts of climate change, as well as structural inequalities and marginalization of actors, within food systems must be taken into consideration. The local food systems observed in this research were built on shaky foundations and are not able to respond to shocks such as the measures imposed in response to COVID-19. For small-scale farmers to contribute adaptive and transformative capacities to restructuring local food systems, a broader, holistic, multi-level strategy must be applied, which includes environmental factors, issues of governance and inclusion, and related policy measures [40].

Another commonality across the five regions is dietary changes during the COVID-19 crisis. Consumption of vegetables and staples (maize, rice, and bread) increased, while consumption of meat, fish, fruit, oil, and sugar decreased. These results are in line with Devereux et al. (2020) who analyzed World Bank price statistics of June 2020 and found that prices of staple foods, such as maize, meal, and rice, did not significantly rise because of good harvests on the global grain market. However, the COVID-19 restrictions impacted food prices in more localized informal markets, which has a fundamental impact on marginalized communities [41]. According to Sen (1983), food security is not a supply-side challenge, but rather a question of availability and affordability [42]. Indeed, rising food prices were exacerbated in Cape Town by the closure of major shopping plazas. Related to this, the debate among co-researchers around the pandemic became a debate around food and hunger in early April.

Referring to the framework presented in Figure 1, we observed that food systems relying on localized agroecological production may be less impacted by the pandemic than food systems relying on external inputs and distant markets, as the example from the remote, rural Toraja demonstrates. Among Toraja farmers, there was a high level of collective action and community-oriented solutions, as part of social capital. This points to the high adaptive capacity of small-scale farming systems in Toraja. This flexibility provides these systems with transformative capacity and potential for change. Indeed, many farmers started to implement solutions during the initial phase of the COVID-19 crisis, even though most of these solutions are "low entry barrier solutions" for which only little financial capital or planned support is required. These strategies are largely implemented autonomously and without support by government. In Masvingo and Cape Town, small-scale farmers and the informal food sector are largely invisible and were excluded from governmental support; however, this led 
to autonomous actions. It is important to understand which strategies were developed to identify the gaps caused by COVID-19 measures and how the fragility of food systems can be addressed in the future.

\subsection{COVID-19: A Gendered Analysis}

This research provides insights into the vulnerabilities of each countries' food system through a producer lens, particularly highlighting gender differences, which were aggravated by COVID-19 intervention measures. Frankenberger et al. (2012) speaks about long-term stress factors [17], particularly among marginalized communities such as small-scale family farms. Long-term trends, such as gender inequalities and climate change, could exacerbate shocks such as COVID-19. Gender inequality is a major root cause of the fragility of food systems.

This study, particularly the contextualization of the information gained through co-researchers, demonstrates that the adaptive capacity of women farmers is higher than that of their male counterparts. For example, developing solutions was mostly done by women and recognized as such. Women in the study locations are traditionally the primary decision makers around food growing, purchase, preparation, and consumption, so would have more internal motivation to innovate and cope. This resonates with Andrews et al. (2019) who state that "[w]omen are, and have always been, central to the creation of radical food politics that have the power to reconnect us with nature, remake social relations, and prioritize intersectional justice" [43]. This is particularly obvious in the case of Masvingo and, to a lesser extent, Cape Town. Global reports [44-47] suggest that women tend to be more disadvantaged during food crises, but actively drive crisis response [48]. Women also applied more coping strategies in three of the four studied food regions. Although women in Cape Town were less able than men to gain permits to access their farms, because their domestic duties limited their time to complete the application process, they initiated a network to grow seedlings to address shortage of inputs during the lockdown. In Masvingo, women farmers ensured that seeds were available for the upcoming planting season. For example, they organized a WhatsApp swap with other women farmers, established kitchen gardens during the lockdown (an additional activity to their farm work), and limited their daily food portions. In Indonesia, while men are the official household head and government assistance is directed at them, women are responsible for bringing family meals to the table and felt extra pressure to maintain this task during the social restrictions. Therefore, women sought to creatively seek solutions to overcome the food supply problem for their families. Women increased vegetable production in kitchen gardens, particularly their own family's consumption.

\subsection{Reflections on the Research Process}

In line with Bello (2020), the author collective agrees that one should not let a good crisis go to waste [9]. This research was initiated by farmers in Cape Town and expanded to other food regions, which allowed for fast, real-time data collection through innovative digital survey techniques and a co-research process. During this process, survey questions were further adapted, more precisely defined, and contextualized by co-researchers. The research consortium was able to build upon existing relationships, which was crucial for the realization of this study. Mutual trust, joint experience on how to engage in and comply with co-research, and a common will to gain a deeper understanding of the situations on the ground are essential for remote surveys across regions. Co-research is regarded as a step toward democratizing research and enables the "researched" to become owners of the results. In fact, by jointly defining the scope of the study, collecting data, making regular virtual presentations and discussions of the results, a strong commitment of the farmers, practitioners, and academically affiliated colleagues was maintained along the process. A democratic research process requires regular communication and exchange, but also, particularly in times of social distancing, an existing and trusting network of practitioners and academics.

Linked to the above, an important aspect of conducting research during the COVID-19 restrictions is having access to free or affordable internet connection. The provision of airtime to co-researchers 
allowed them to overcome financial constraints to participation in the study. In times of curfews, digital communication is essential, and is critical for food security. In Cape Town, for example, WhatsApp groups were used to communicate regarding the sharing of food. In Maputo, digital communication allowed farmers to contact agricultural extension during the restrictions. In Java, farmers used apps to sell their crops. An important question is, therefore, should communication become a common to overcome the digital divide that hinders equal participation in food systems for marginalized groups?

It must be emphasized that this research was conducted during an exceptional time and for a limited period. This does not allow us to draw general conclusions or to make policy recommendations for these five research sites. However, our findings provide first-hand insights into the impact of COVID-19 on vulnerable local food systems and actors within these systems. This has allowed us to draw comparisons between the five regions.

\section{Conclusions: Call for a Transition toward Resilient Local Food Systems}

The COVID-19 crisis has shown that it is not only small-scale farmers who need to increase their adaptive capacity to improve resilience; decision-makers also need to ensure that those who provide small-scale solutions, in particular women farmers, are an integral part of food systems and have the capacity to improve their resilience to shocks, especially when an enabling environment is lacking. For Cape Town, land and land access remain the burning issues with key goals being the reduction of the burden of farming in marginalized communities, improvement of the poorest soils in the city, and overcoming space limitations to grow food for communities. Beyond structural support such as a simplified procedures for land access and farm access, financial support (beyond donations) to the locally mushrooming food systems solutions, such as the farmers' community kitchens, is required. For Maputo, to guarantee that products reach the customers in a safe way, farmer groups call for better transport and intermediary systems that allow food hygiene for consumers and transparency for producers. For Masvingo, food aid is most essential for the short term, and long-term needs include affordable farming inputs, as price hikes and price fluctuation regularly challenge the resilience of farming. In Indonesia, market access is still a challenge and requires government support to logistics and infrastructure to allow farmers to access markets for fresh produce. Another promising income-generating activity identified by local farmers is marketing processed food under their own label, also via social media channels. While small-scale farmers mobilized their social capital resources to act in a flexible manner in the current COVID-19 food crisis, it is insufficient to rely on the adaptive capacity of small-scale farmers only: the multidimensional weaknesses in the food system must be holistically addressed. A phrase that circulated in the last months of research, "building back better", should encourage us to consider what we want to build back and what we want to build forward to address fragilities in current food systems. That is, we must conscientiously seek to design local food systems that complement global systems and challenge power dynamics by enabling actors to obtain agency in their food choices. In all research sites, we experienced that the collective action of small-scale farmers was crucial for information sharing, exchange, and support and that small-scale farmers, as actors within their local food systems, have a crystal-clear idea and vision of how their food systems should look. Their lack of governance participation illustrates, once again, that it is not a matter of building back, but of rethinking and rephrasing the dialogue around food. When advocating for agroecological farming systems with the capacity to cope, to adapt, and to transform food systems toward resilience, decision-makers and civil society are required to fully integrate and listen to small-scale farmers, particularly women farmers, for example in local food councils that enable farmers to become active and visible actors of resilient, local food systems. 
Author Contributions: The collective of authors contributed as follows: conceptualization: N.P., S.S., D.T., and A.K.; methodology: T.R., N.P. and S.S.; software: N.P. and D.H.; formal analysis: E.N.A., J.K., N.S., S.S. and N.P.; investigation: N.B., A.L., F.N., K.A. and T.R.; writing-original draft preparation: N.P.; writing-review and editing: D.H., A.K., S.L., I.R., S.S., D.T. and H.S.; project administration: N.P.; funding acquisition: S.S. and N.P. All authors have read and agreed to the published version of the manuscript.

Funding: This research was funded by foundation fiat panis, Ulm, and Freunde und Förderer des SLE e.V., an affiliated organization to the Centre of Rural Development (SLE) at the Humboldt-Universität zu Berlin.

Acknowledgments: Our deepest thanks to more than seven hundred farmers in Indonesia, Mozambique, South Africa, and Zimbabwe, who have constantly supported this research as co-researchers and who provided information, reflections, and guidance.

Conflicts of Interest: The authors declare no conflict of interest.

\section{References}

1. IFAD. Smallholders, Food Security, and The Environment; International Fund for Agricultural Development: Rome, Italy, 2013.

2. Addressing Inequality in Time of COVID-19. Available online: http://www.fao.org/documents/card/en/c/ ca8843en/ (accessed on 9 June 2020).

3. Impact of COVID-19 on Informal Workers. Available online: http://www.fao.org/documents/card/en/c/ ca8560en/ (accessed on 9 June 2020).

4. FAO; WFP. FAO-WFP Early Warning Analysis of Acute Food Insecurity Hotspots: July 2020; Food and Agriculture Organization of the United Nations and World Food Programme: Rome, Italy, 2020. [CrossRef]

5. Mukiibi, E. COVID-19 and the state of food security in Africa. Agric. Hum. Values 2020, 37, 627-628. [CrossRef] [PubMed]

6. Béné, C. Resilience of local food systems and links to food security-A review of some important concepts in the context of COVID-19 and other shocks. Food Secur. 2020, 12, 805-822. [CrossRef]

7. IPES-Food. COVID-19 and The Crisis in Food Systems: Symptoms, CAUSES, and Potential Solutions. 2020. Available online: http://www.ipes-food.org/_img/upload/files/COVID-19_CommuniqueEN\%283\%29.pdf (accessed on 8 June 2020).

8. Pretty, J. New opportunities for the redesign of agricultural and food systems. Agric. Hum. Values 2020, 37, 629-630. [CrossRef] [PubMed]

9. Bello, W. Never Let a Good Crisis Go To Waste-The COVID-19 Pandemic and the Opportunity For Food Sovereignty. Transnational Institute. 2020. Available online: https://www.tni.org/en/publication/never-let-agood-crisis-go-to-waste (accessed on 9 June 2020).

10. Moyer, J. A time of reflection: A time for change. Agric. Hum. Values 2020, 37, 581-582. [CrossRef]

11. Jayaraman, S. Building power through crisis. Agric. Hum. Values 2020, 37, 663-664. [CrossRef] [PubMed]

12. Altieri, M.A.; Nicholls, C.I. Agroecology and the emergence of a post COVID-19 agriculture. Agric. Hum. Values 2020, 37, 525-526. [CrossRef]

13. Eskender, B.; Steinke, J.; van Etten, J.; Reidsma, P.; Fadda, C.; Mittra, S.; Mathur, P.; Kooistra, L. What Are the Prospects for Citizen Science in Agriculture? Evidence from Three Continents on Motivation and Mobile Telephone Use of Resource-Poor Farmers. PLoS ONE 2017, 12, e0175700. [CrossRef]

14. FAO. RIMA-II: Resilience Index Measurement and Analysis-II; Food and Agriculture Organization of the United Nations: Rome, Italy, 2016.

15. Tendall, D.M.; Joerin, J.; Kopainsky, B.; Edwards, P.; Shreck, A.; Le, Q.B.; Kruetli, P.; Grant, M.; Six, J. Food system resilience: Defining the concept. Glob. Food Secur. 2015, 6, 17-23. [CrossRef]

16. Martin, R. Regional Economic resilience, hysteresis and recessionary shocks. J. Econ. Geogr. 2012, 12, 1-32. [CrossRef]

17. Frankenberger, T.; Spangler, T.; Nelson, S.; Langworthy, M. Enhancing Resilience to Food Security Shocks in Africa. Discussion Paper. Available online: www.fsnnetwork.org/sites/default/files/discussion_paper_usaid_ dfid_wb_nov._8_2012.pdf (accessed on 8 July 2020).

18. Small Family Farms Country Factsheet Indonesia. Available online: http://www.fao.org/3/I8881EN/i8881en. pdf (accessed on 17 July 2020).

19. Lowder, S.K.; Skoet, J.; Raney, T. The Number, Size and Distribution of Farms, Smallholder Farms, and Family Farms Worldwide. World Dev. 2016, 87, 16-29. [CrossRef] 
20. World Food Programme. Indonesia COVID-19: Economic and Food Security Implications; Vulnerability Analysis and Mapping (VAM) Unit: Central Java, Indonesia; WFO: Rome, Italy, 2020.

21. WHO. Coronavirus Disease (COVID-19) Dashboard. Available online: https://covid19.who.int/table (accessed on 31 August 2020).

22. McCordic, C.; Abrahamo, E. Family Structure and Severe Food Insecurity in Maputo and Matola, Mozambique. Sustainability 2019, 11, 267. [CrossRef]

23. Battersby, J.; Crush, J. The Making of Urban Food Deserts. In Rapid Urbanisation, Urban Food Deserts and Food Security in Africa; Battersby, J., Crush, T., Eds.; Springer International Publishing: Basel, Switzerland, 2016; pp. 1-18. [CrossRef]

24. Raimundo, I.; Frayne, B. Impacts of climate change in migration and food security in Maputo, Mozambique. In Climate Change, Assets and Food Security in Southern African Cities; Frayne, B., Moser, C., Ziervogel, G., Eds.; Routledge: London, UK, 2012; pp. 97-109. [CrossRef]

25. Engel, E.; Paganini, N.; Chicamisse-Mutisse, L.; Cumbana, I.; Fiege, K.; Kühn, A.; Kanosvamhira, T.; Halder, S.; Schelchen, A.; Mfaku, A.; et al. Farming in Cities. Potentials and Challenges of Urban Agriculture in Maputo and Cape Town; SLE Discussion Paper; Urban Research Farmer Group Cape Town, SLE: Berlin, Germany, 2019. [CrossRef]

26. SA's Unemployment Rate Could Reach 40\% Due to COVID-19-Mogajane. Available online: https://ewn.co. za/2020/05/04/sa-s-unemployment-rate-could-possibly-reach-40-due-to-covid-19-mogajane\# (accessed on 31 August 2020).

27. Hunger Numbers: Millions, Millions, Millions Need Food. Available online: https://www.dailymaverick.co. za/article/2020-05-08-hunger-numbers-millions-millions-millions-need-food/ (accessed on 31 August 2020).

28. Battersby, J. South Africa's lockdown regulations and the reinforcement of anti-informality bias. Agric. Hum. Values 2020, 37, 543-544. [CrossRef] [PubMed]

29. The World Bank in Mozambique. Available online: https:/www.worldbank.org/en/country/mozambique/ overview (accessed on 12 July 2020).

30. Devereux, S.; Hochfeld, T.; Karriem, A.; Mensah, C.; Morahanye, M.; Msimang, T.; Mukubonda, A.; Naicker, S.; Nkomo, G.; Sanders, D.; et al. School Feeding in South Africa: What we know, what we don't know, what we need to know, what we need to do. DST NRF Cent. Excell. Food Secur. Work. Pap. 2018, 4. Available online: https://foodsecurity.ac.za/publications/school-feeding-in-south-africa-what-we-knowwhat-we-dont-know-what-we-need-to-know-what-we-need-to-do/ (accessed on 31 August 2020).

31. Battersby, J.; Marshak, M.; Mngqibisa, N. Mapping the Invisible: The Informal Food Economy of Cape Town, South Africa. Urban Food Secur. Ser. 2016, 24, 1-38. [CrossRef]

32. Mbalo Brief. June 2020. Available online: http://www.statssa.gov.za/?p=13411\#: \{\}:text=According\%20to\% 20Statistics\%20South\%20Africa, the \%20first \%20quarter\%20of\%202020 (accessed on 31 August 2020).

33. Dinbabo, M.; Karriem, A.; Penderis, S.; May, J.; Fulcher, C.; Belebema, M.; Mogatosi, T.; Zinja, P.; Gangen, N.; Adams, R.; et al. Food Choices and Body Mass Index (BMI) in Adults and Children: Evidence From the National Income Dynamics Study (NIDS) and Empirical Research From Khayelitsha and Mitchells Plain in South Africa; Institute for Social Development, University of the Western Cape: Cape Town, South Africa, 2017.

34. Diabetic Patients Make up a Third of WC COVID-19 Fatalities-Data. Available online: https://ewn.co.za/ 2020/05/07/diabetic-patients-make-up-a-third-of-wc-COVID-19-fatalities-data (accessed on 10 June 2020).

35. Strauss, M. A Historical Exposition of Spatial Injustice and Segregated Urban Settlements in South Africa. Fundamina 2019, 25, 135-168. [CrossRef]

36. Buthelezi, N.; Karriem, A.; Lemke, S.; Paganini, N.; Stöber, S.; Swanby, H. Invisible urban farmers and a next season of hunger-Participatory co-research during lockdown in Cape Town, South Africa. Opinion Piece. Crit. Food Stud. Transdiscip. Humanit. Approach. 2020. [CrossRef]

37. Chingarande, D.; Matondi, P.; Mugano, G.; Chagwiza, G.; Hungwe, M. Zimbabwe Food Security Desk Research: Masvingo Province; Research Technical Assistance Center: Washington, DC, USA, 2020.

38. Manjengwa, J.; Hanlon, J. Who will make the "best" use of Africa's land? Lessons from Zimbabwe. Third World Q. 2014, 35, 980-995. [CrossRef]

39. About Kobotoolbox. Available online: https://www.kobotoolbox.org/\#about (accessed on 22 June 2020). 
40. Lemke, S.; Bellows, A.C. Sustainable food systems, gender, and participation: Foregrounding women in the context of the right to adequate food and nutrition. In Gender, Nutrition, and the Human Right to Adequate Food: Toward an Inclusive Framework; Bellows, A.C., Valente, F.L.S., Lemke, S., Núñez, M.D.B.d.L., Eds.; Routledge, Taylor and Francis Group: London, UK, 2016; pp. 254-340.

41. Devereux, S.; Béné, C.; Hoddinott, J. Conceptualising COVID-19's impacts on household food security. Food Secur. 2020, 12, 769-770. [CrossRef]

42. Sen, A. Poverty and Famines: An Essay on Entitlement and Deprivation; Oxford University Press: Oxford, UK, 1983. [CrossRef]

43. Food Security and Covid-19. Available online: https://www.worldbank.org/en/topic/agriculture/brief/foodsecurity-and-covid-19 (accessed on 31 August 2020).

44. Andrews, D.; Smith, K.; Morena, M.A. Enraged: Women and Nature. Women. Power Food Struggles 2019, 11, 6-15. Available online: https://www.righttofoodandnutrition.org/files/rtfn-watch11-2019_eng-6-15.pdf (accessed on 8 August 2020).

45. Nanthini, S.; Nair, T. COVID-19 and the Impacts on Women. NTS Insight, IN20-05. 2020. Available online: https://www.think-asia.org/bitstream/handle/11540/12302/NTS-Insight_COVID-19-and-the-Impactson-Women-30July2020.pdf? sequence=1 (accessed on 8 August 2020).

46. Cock, J. A feminist response to the food crisis in contemporary South Africa. Agenda 2016, 30, 121-132. [CrossRef]

47. Fanzo, J.; Covic, N.; Dobermann, A.; Spencer, H.; Herrero, M.; Pingali, P.; Staal, S. A research vision for food systems in the 2020s: Defying the status quo. Glob. Food Secur. 2020, 26, 100367. [CrossRef]

48. Patel, J.A.; Nielsen, F.B.H.; Badiani, A.A.; Assi, S.; Unadkat, V.A.; Patel, B.; Ravindrane, R.; Wardle, H. Poverty, Inequality \& COVID-19: The Forgotten Vulnerable. Public Health 2020, 183, 110-111. [CrossRef] [PubMed]

Publisher's Note: MDPI stays neutral with regard to jurisdictional claims in published maps and institutional affiliations. 